\title{
Economic and environmental performances of organic photovoltaics with battery storage for residential self-consumption
}

Chatzisideris, Marios D.; Ohms, Pernille K.; Espinosa, Nieves; Krebs, Frederik C.; Laurent, Alexis

Published in:

Applied Energy

Link to article, DOI:

10.1016/j.apenergy.2019.113977

Publication date:

2019

Document Version

Peer reviewed version

Link back to DTU Orbit

Citation (APA):

Chatzisideris, M. D., Ohms, P. K., Espinosa, N., Krebs, F. C., \& Laurent, A. (2019). Economic and environmental performances of organic photovoltaics with battery storage for residential self-consumption. Applied Energy, 256, [113977]. https://doi.org/10.1016/j.apenergy.2019.113977

\section{General rights}

Copyright and moral rights for the publications made accessible in the public portal are retained by the authors and/or other copyright owners and it is a condition of accessing publications that users recognise and abide by the legal requirements associated with these rights.

- Users may download and print one copy of any publication from the public portal for the purpose of private study or research.

- You may not further distribute the material or use it for any profit-making activity or commercial gain

- You may freely distribute the URL identifying the publication in the public portal 


\title{
Economic and environmental performances of organic photovoltaics with battery storage for residential self-consumption
}

\author{
Marios D. Chatzisideris ${ }^{a}$, Pernille K. Ohms ${ }^{b}$, Nieves Espinosa ${ }^{c}$, \\ Frederik C. Krebs ${ }^{\text {a }}$, Alexis Laurent ${ }^{b, *}$
}

\begin{abstract}
${ }^{a}$ Department of Energy Conversion and Storage, Technical University of Denmark, Roskilde, Denmark

${ }^{\mathrm{b}}$ Quantitative Sustainability Assessment Group, Sustainability Division, DTU Management, Technical University of Denmark (DTU), Lyngby, Denmark

${ }^{\mathrm{c}}$ European Commission, Joint Research Centre, Directorate B - Growth and Innovation, Sevilla, Spain
\end{abstract}

* Corresponding author: $\underline{\text { alau@dtu.dk }}$

\begin{abstract}
Recent economic developments have signalled that self-consumption of photovoltaics (PV)-generated electricity could be financially more attractive than exporting it to the grid in many countries. As an emerging PV technology, organic photovoltaics (OPV) have been recognized as potential bearer of economic and environmental gains. Yet, could OPV deliver a profitable investment and environmental impact reductions in the context of residential electricity self-consumption? Here, we conduct a study of unprecedented scoping that combines both economic analysis and life cycle assessment to gauge OPV self-consumption with or without battery storage for household settings. The upscaling of OPV technologies from pilot- to industrial scale was modelled, and we used the two contrasting cases of Denmark and Greece to identify potential patterns. Our economic results indicate that the addition of battery storage is not financially viable unless battery costs are reduced by more than $10 \%$ for Greece and 30\% for Denmark. Furthermore, we identify OPV cost thresholds of $0.9 € / \mathrm{Wp}$ for Denmark and $1.6 € / \mathrm{Wp}$ for Greece, below which OPV-battery systems are more cost-effective than OPV systems without battery. Building on the economic analysis, we find that battery storage can improve the environmental performances of OPV systems under certain conditions on the battery costs, the capacity of the cost-optimal OPV-battery system, and the environmental impacts of the battery. Furthermore, the composition of the electricity grid mix in the country studied was found to be an important factor to determine where OPV self-consumption was environmentally beneficial. These findings can support energy policy-makers in their development of energy strategies as well as OPV technology developers, who should adopt a systemic approach and integrate battery storage and the balance of system within their development phases.
\end{abstract}


Chatzisideris M.D., Ohms P.K., Espinosa N., Krebs F.C., Laurent A., 2019. Economic and environmental performances of organic photovoltaics with battery storage for residential self-consumption. Applied Energy 256, 113977, 1-13. DOI: https://doi.org/10.1016/j.apenergy.2019.113977

\section{Introduction}

Photovoltaics (PV) is a key renewable energy technology, which could significantly contribute to tackle climate change and other environmental impacts as well as meet growing electricity demands. In its latest available World Energy Outlook, the International Energy Agency emphasised the increasing competitiveness of solar PV, which is predicted to outrun in installation capacity wind power before 2025, hydropower around 2030 and coal before 2040.[1] By 2040, PV are projected to be the least-cost source of new electricity generation for many countries.[1,2] PV can thus be expected to play an increasingly important role in future energy systems.[2]

In that setting, the combination of continuously decreasing PV module costs, increasing retail electricity prices and fading feed-in tariffs has made self-consumption of PV-generated electricity financially more attractive than exporting it to the grid,[3,4] e.g. in the European Union.[5-7] Residential electricity consumers can install PV systems to generate their own electricity and decrease their electricity bills, with a possibility to additionally integrate battery storage to further decrease these electricity bills.[8] Since battery costs are declining rapidly, PV-battery systems are likely to be the most cost-effective solution compared to PV-only systems or to the grid in the future.[9] However, PV-only and PV-battery systems are still not cheap enough to compete with electricity supply from the grid, and still rely on government support through net-metering and self-consumption schemes.

Among the wide range of PV technologies, organic photovoltaics (OPV) is a promising technology, which utilises organic molecules and polymer materials to capture light and transform it to electricity.[10-13] Organic photovoltaic cells are fabricated in multiple layers where solution-based materials are deposited on a plastic substrate through roll-to-roll printing and coating techniques under ambient conditions, similar to newspaper printing.[14] These fabrication settings offer great potential for reducing PV technology costs down to $0.05 € / \mathrm{Wp}$ according to cost projections $[15,16]$, while more mature Si-based PV modules costs remain at 0.5-0.6 $€ / \mathrm{Wp}$ for example in Germany at the end of 2018.[17] Although lower power conversion efficiencies and shorter lifetimes have so far prevented OPV from entering the PV market, it may therefore be expected to become a major PV technology in a near future,[15] and hence play a significant role in PV self-consumption. In this context, anticipating future technological improvements of OPV cells, there is a need to explore the potential that OPV systems can have in supporting electricity self-consumption: what potential economic and environmental gains could they bring in such applications? This study is intended to tackle that important research question, which can help energy policy-makers steer energy planning strategies and aid PV stakeholders at large focus on key aspects in the development of OPV technologies so as to optimise both economic and environmental gains.

\section{Literature review}

State-of-the-art OPV research argues that proof of concept has been demonstrated for OPV technologies by reporting the operational stability and monitoring of a pilot OPV solar park over a 2-year period.[15] Most importantly, Carle et al. [15] emphasize that, to transition OPV technologies from the research lab to the market, researchers need to change their focus from scientific achievements to technical achievements. This would entail addressing aspects such as total OPV system costs, life cycle environmental impacts, resource depletion, safety and handling.[15] In this study, we focus on the first two aspects: the economic costs and gains, and life cycle environmental impacts of the OPV systems. State-of-the-art for both aspects is summarised in the following subsections. 
Chatzisideris M.D., Ohms P.K., Espinosa N., Krebs F.C., Laurent A., 2019. Economic and environmental performances of organic photovoltaics with battery storage for residential self-consumption. Applied Energy 256, 113977, 1-13. DOI: https://doi.org/10.1016/j.apenergy.2019.113977

\subsection{Economic analyses of PV/OPV systems}

In the context of PV self-consumption, a number of studies have investigated the economic performances of PV systems, with different levels of analysis, e.g. relating PV systems characteristics, like its size or the presence of storage capacity, to economic output parameters, like profitability or electricity costs.[18] A recent example is the study by Schram et al. [19], who explored the potential of battery storage in PV residential self-consumption to absorb the peak demand and reduce the pull from the utility grid mix, using a city in the Netherlands as specific case. They found large benefits in such settings, with dependence of the storage capacity (ranges of 0.5-0.9 $\mathrm{kWh}$ ) on the household types, PV system size, net-metering scheme characteristics and battery control strategies. In other studies, Parra and Patel [4] and Roberts et al. [8] arrived at similar conclusions, where both studies, focusing on the United Kingdom and Australia as cases, showed that the combination of demand peak shaving and PV self-consumption brought out the most economic values, thus leading to specific recommendations to energy policy stakeholders. These studies clearly point out to the relevance of investigating the effects of battery storage on the performances of PV self-consumption, and of determining optimal configurations for a given setting.

Despite the numerous studies assessing economic aspects of PV, few studies have analysed OPV technologies, and they mainly focused on analysing OPV costs [16,20,21]. For example, Machui et al. [16] have documented OPV material costs based on real data from a pilot-scale production line, and have projected OPV material costs assuming a future $100 \mathrm{GW}$-scale production. Gambhir et al. [20] have calculated future OPV cost estimates by considering the effect of scale-up on manufacturing process costs, and by introducing stochastic Monte Carlo analysis to account for uncertain parameters affecting technology costs. Only one recent study by Chatzisideris et al. [22] was found to specifically address OPV in the context of electricity self-consumption. The authors evaluated the investment profitability of OPV systems installed for selfconsumption at houses in Denmark and Greece. They demonstrated that, when produced at an industrial-scale manufacturing cost of $1.53 € / \mathrm{Wp}$, OPV systems could offer a $38 \%$ electricity bill reduction for households in Greece, which benefits from an attractive annual-based net-metering scheme, but only a $6.5 \%$ bill reduction for households in Denmark, which has a less profitable hourly-based self-consumption scheme in place. However, a major limitation of that study is that it does not account for the potential economic effect of battery storage on OPV self-consumption.

\subsection{Environmental performances of OPV systems}

Despite being subject of many occurrences and unfortunate recommendations in the scientific literature, including in the PV field, the terms of environmental sustainability or environmental burden can very often not be reduced to just evaluating climate change impacts or inventorying CO2 emissions.[23,24] While PV systems carry little impacts during their operations, they are indeed associated with non-negligible impacts during their production and end-of-life, with for example releases of toxic substances like metals (from mining, manufacturing processes, etc.) impacting ecosystems and human health, or potential depletion of metals and minerals.[24] All these environmental problems need to be considered to avoid burden shifting from one component of the PV systems to another or from one environmental problem to another. Adopting a holistic perspective, which does not just look at $\mathrm{CO} 2$ emissions and which is not limited to the operation stage of the PV systems, is therefore necessary when one aims to gauge the environmental impacts or performances of PV systems.[25]

To ensure such perspective, life cycle assessment (LCA) can be used. LCA is a widely used, ISOstandardised methodology to quantify a large variety of environmental impacts of a product, technology or 
Chatzisideris M.D., Ohms P.K., Espinosa N., Krebs F.C., Laurent A., 2019. Economic and environmental performances of organic photovoltaics with battery storage for residential self-consumption. Applied Energy 256, 113977, 1-13. DOI: https://doi.org/10.1016/j.apenergy.2019.113977

system in a life cycle perspective, from raw materials extraction through manufacturing and use/operation up to its end-of-life, according to ISO 14040/ 14044:2006 standards.[26,27] Until now, most LCA studies of OPV technologies have focused on systems that export all generated electricity to the grid.[28-30] However, this modelling scope is not fit when assessing OPV self-consumption. To the authors' knowledge, only one study has investigated the environmental performance of an OPV system installed for self-consumption including battery storage.[31] That explorative study by Chatzisideris et al. [31] however bears important limitations in (i) its reliance on the combined results from previous LCA studies of a pilot-scale OPV system [28] and a sodium/nickel chloride battery [32], precluding a fully consistent LCA model; (ii) its sole consideration of two environmental impact categories, i.e. climate change and chemical releases impacting human health, thus not addressing other relevant environmental problems (e.g. metal resource depletion) and carrying the risk of environmental burden-shifting [33]; (iii) its primary focus on Denmark, hence not exploring geographical variability; and (iv) its lack of sensitivity to technical specifications (e.g. efficiencies, lifetimes) precluding any analysis of technology upscaling from pilot-scale to full commercial/industrial scale. To date, no LCA study has thus assessed the full environmental impacts of OPV systems with and without battery storage installed at houses for self-consumption. By extension, no study has integrated the comprehensive analysis of both economic and life cycle environmental impacts associated with residential OPV systems.

The aim of this paper is therefore to bridge the above knowledge gaps and assess for the first time whether the integration of battery storage into OPV systems can offer financial and environmental benefits to the consumers and the society. We assess the economic performances by calculating the potential profits from investing in OPV systems with and without battery storage installed at houses for self-consumption over a 20year time horizon in two different countries, namely Denmark and Greece, as case studies. The same assessment is carried out from an environmental perspective. We conduct a full LCA study of OPV systems installed for self-consumption taking into account the effects of scaling up OPV technologies from pilot-scale to industrial-scale manufacturing settings and the effects of integrating battery storage. The geographical scope of the study was motivated by previous works (see ref. [22]) and important contextual discrepancies including differences in solar irradiation, renewable energy policy and PV regulatory framework. Therefore, by assessing the economic and environmental effects of battery storage, this study supports OPV technology developers and energy policy makers in developing and evaluating the potential of OPV to deliver low-cost and environmentally-friendly electricity generation.

\section{Methods}

\subsection{Modelling framework}

A modelling framework, which consists of six modelling steps, was developed to assess the economic and environmental performances of OPV systems with and without battery storage. Figure 1 illustrates the modelling framework and outlines key input and output parameters of each modelling step. Steps 1-5 have first been presented in ref. [22] to assess the economic performance of OPV-only systems; in this work, battery storage capability has been integrated, and the assessment of the environmental performance has been developed (i.e. Step 6 in Figure 1).

As shown in Figure 1, the sequence of the modelling steps deliberately adopted a consumer perspective of prioritising financial motives over environmental concerns. Financial motive is the key factor behind the decision of the majority of residential electricity consumers to invest or not in renewable energy and energy efficiency technologies, as suggested by previous studies in Sweden [34], Italy [35], the United Kingdom [36] 
Chatzisideris M.D., Ohms P.K., Espinosa N., Krebs F.C., Laurent A., 2019. Economic and environmental performances of organic photovoltaics with battery storage for residential self-consumption. Applied Energy 256, 113977, 1-13. DOI: https://doi.org/10.1016/j.apenergy.2019.113977

and Germany [37]. For that reason, the assessment of the environmental impacts (in Step 6) was specifically applied to the cost-optimal OPV-only and OPV-battery system set-ups, which were calculated by the preceding investment profitability evaluation (in Step 5). A reverse sequence (i.e. conducting the profitability evaluation study only on pre-identified environmentally friendly solutions) may also be envisaged depending on the national or local context of the study, including users' behaviours. When assessing the profitability of OPVbattery systems (in Step 5), the objective is to identify the specific OPV-battery system that offers a higher investment profit than the cost-optimal OPV-only system. The logic behind this approach is again that an electricity consumer would prefer an OPV-battery system to an OPV-only system primarily on financial grounds.[37] 
Chatzisideris M.D., Ohms P.K., Espinosa N., Krebs F.C., Laurent A., 2019. Economic and environmental performances of organic photovoltaics with battery storage for residential self-consumption. Applied Energy 256, 113977, 1-13. DOI: https://doi.org/10.1016/j.apenergy.2019.113977

inputs

Modelling framework

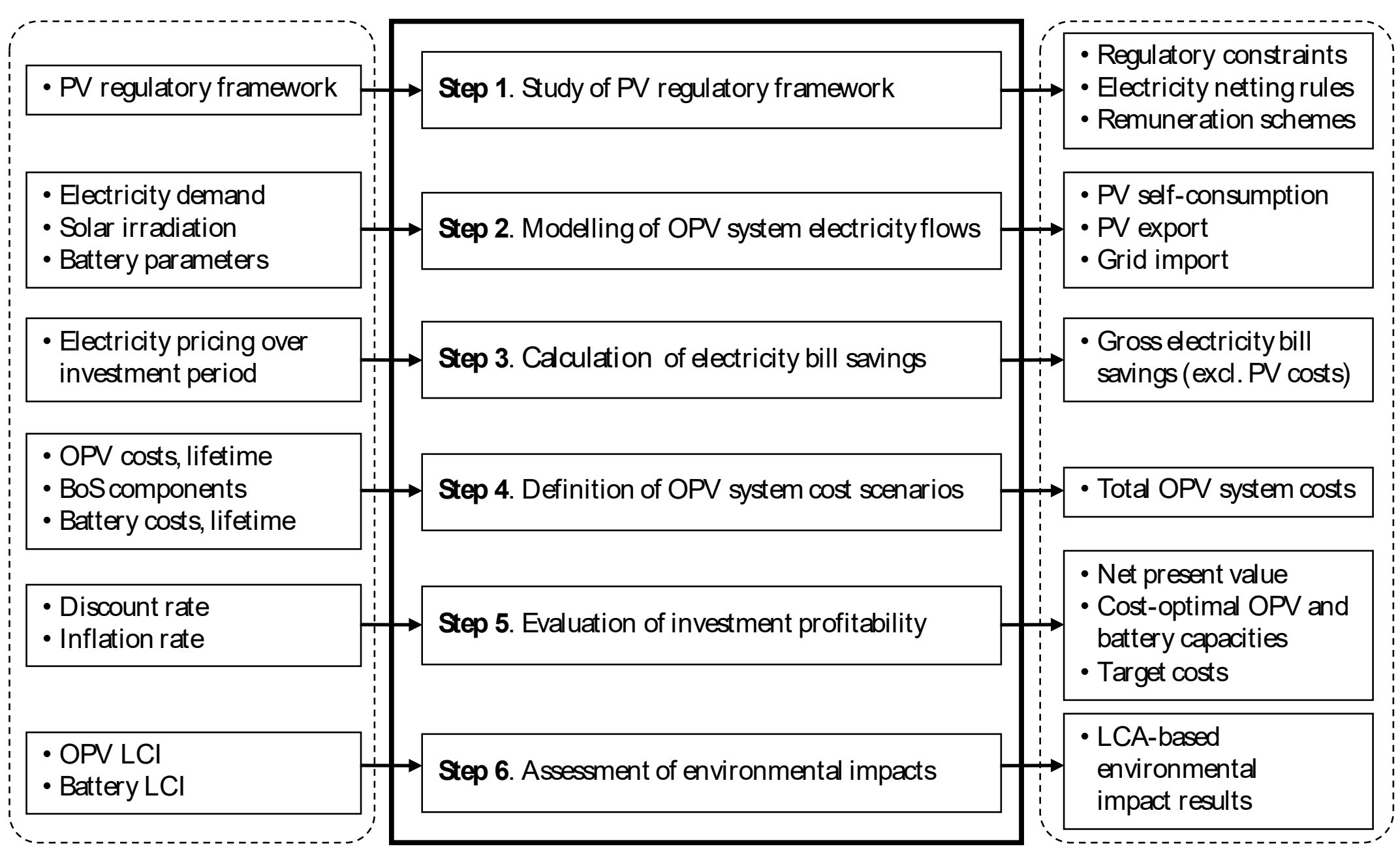

Figure 1. Developed modelling framework. It specifies model inputs and outputs to assess the economic and environmental performances of OPV systems with and without battery storage for self-consumption. Framework adapted from ref. [22]. 
Chatzisideris M.D., Ohms P.K., Espinosa N., Krebs F.C., Laurent A., 2019. Economic and environmental performances of organic photovoltaics with battery storage for residential self-consumption. Applied Energy 256, 113977, 1-13. DOI: https://doi.org/10.1016/j.apenergy.2019.113977

\subsection{System description and modelling of electricity flows}

In Step 1 (Figure 1), a careful examination of the Danish and Greek PV regulatory frameworks provided the basis for identifying the modelling and data requirements. Feeding into Step 2, an OPV system model was developed to simulate the operation of an OPV-only system (System A) and an OPV-battery system (System B) installed at a household with an average electricity consumption of $4000 \mathrm{kWh} / \mathrm{year}$, applicable to both Denmark and Greece (see Figure 2). The baseline system is defined by the electricity demand of the house being fully satisfied by electricity imports from the grid. In System A, an OPV system is installed for selfconsumption. The part of the OPV generation that is consumed by the household (termed 'OPV selfconsumption') partly satisfies the house's electricity demand, thus reducing electricity imports from the grid. The part of the OPV generation that is not consumed by the house is exported to the grid (termed 'OPV export'), thus substituting electricity generation from other sources in the grid, and hence replacing the associated environmental impacts. In System B, the integration of battery storage enables the OPV system to store excess electricity generated from OPV (termed "OPV generation" in the following), thus increasing OPV self-consumption and further decreasing electricity imports from the grid. Importantly, the OPV system model enabled the calculation of three types of electricity flows among the OPV system, the house and the electricity grid: grid import; OPV (battery) self-consumption; and, OPV (battery) exports.

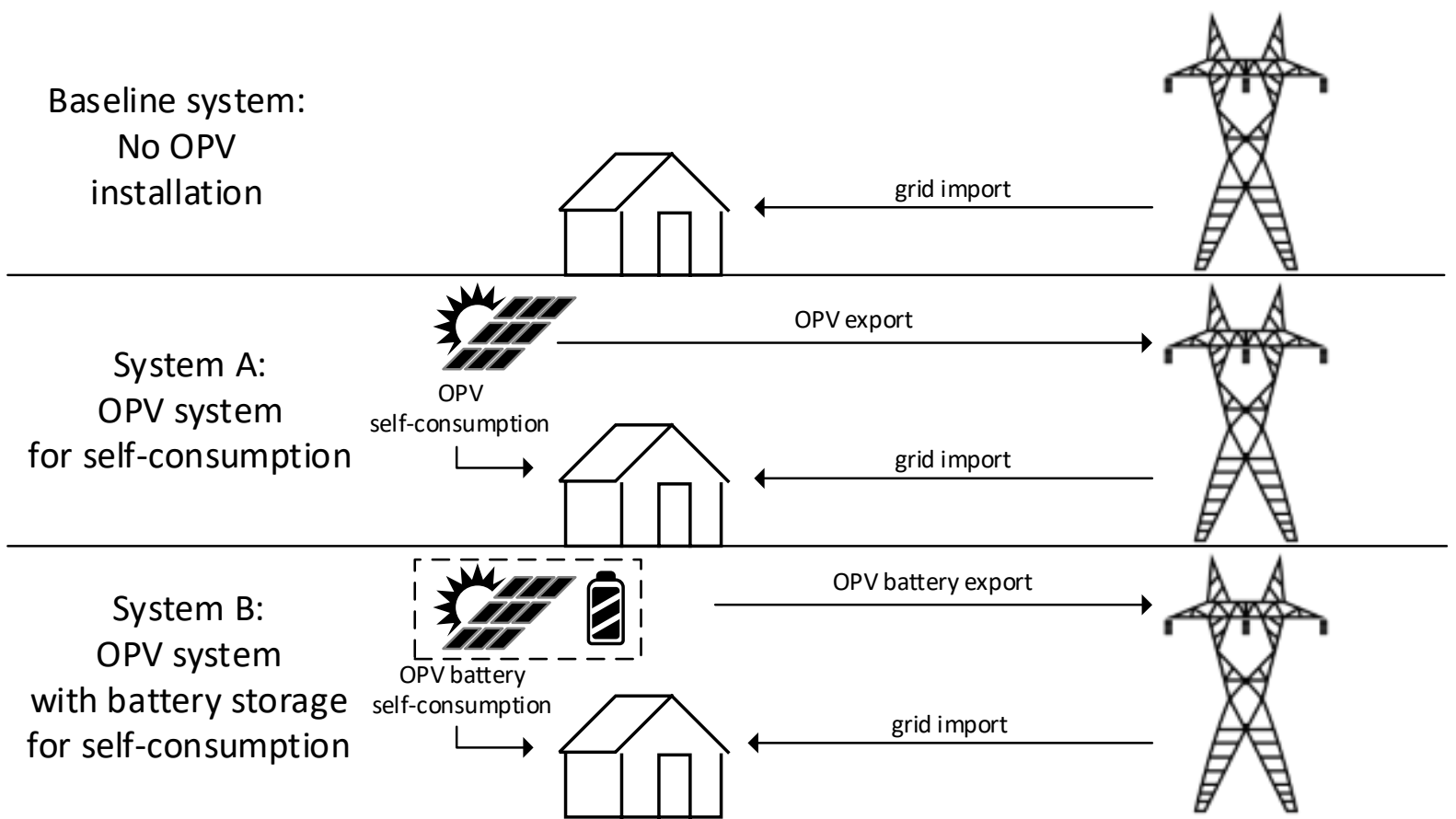

Figure 2. The three systems assessed in this study

Time series data sets of electricity demand and solar irradiation values for the years 2012 (Denmark) and 2014 (Greece) were generated for a reference year, which were used as inputs to the model, assuming no changes in these parameters over the investigated 20-year time horizon (2017-2036) of the OPV system model. The reference year was characterised for the 2 countries using available data about electricity demand, load profiles and solar irradiation in Denmark (year 2012) and Greece (year 2014).[22] Next, OPV system 
Chatzisideris M.D., Ohms P.K., Espinosa N., Krebs F.C., Laurent A., 2019. Economic and environmental performances of organic photovoltaics with battery storage for residential self-consumption. Applied Energy 256, 113977, 1-13. DOI: https://doi.org/10.1016/j.apenergy.2019.113977

yield was calculated based on the solar irradiation data set and OPV parameters according to Table 1. Finally, to simulate the electricity flows, the time series data sets of electricity demand and OPV generation were compared on a time-step basis as described in the study by Chatzisideris et al. [31]. It is noteworthy that the current annual-based net-metering scheme of Greece does not allow the connection of PV systems with battery storage.[38] Therefore, to enable the simulation of the electricity flows and the evaluation of the investment profitability of OPV battery systems, a hypothetical hourly-based self-consumption scheme similar to that of Denmark was assumed and modelled.

Table 1. OPV costs and technical parameters assuming an industrial-scale manufacturing setting.

\begin{tabular}{ll}
\hline Costs and parameters & Industrial-scale OPV \\
\hline OPV foil cost & $9.21 € / \mathrm{m} 2[16]$ \\
Device architecture (active layer materials) & Single device with Ag electrodes (MH301:PCBM) \\
& {$[39]$} \\
Cell efficiency & $10 \%[22]^{, ~ a}$ \\
Fill factor (FF) & $98 \%[16]$ \\
Module lifetime & 10 years $[22]^{, ~ a}$ \\
OPV module cost & $0.094 € / \mathrm{Wp}[16]$ \\
Balance of system cost & $0.6 \$ / \mathrm{Wp}[20]$ \\
Balance of System $(B o S)$ lifetime & 20 years $[20]$ \\
Installation/re-installation cost & $0.51 / 0.26 \$ / \mathrm{Wp}[20]$ \\
Operation \& maintenance service & $0.5 \%$ of modules and BoS costs per year $[20]$ \\
Assumed system lifetime & 20 years \\
Total OPV costs & $1.62 € / \mathrm{Wp}{ }^{\mathrm{b}}$ \\
\hline
\end{tabular}

${ }^{\text {a }}$ Cell efficiency and module lifetime values were based on own assumptions.[22]

${ }^{\mathrm{b}}$ Total OPV costs calculated in this study for OPV with Ag electrodes.

\subsection{Modelling of battery storage}

For the modelling of the battery storage of the OPV-battery system (System B in Figure 2), two key modelling choices were involved, as pointed out by previous studies [9,39]: charging/discharging strategy, and battery technology.

The charging/discharging strategy is generally dependent on the PV regulatory framework and the electricity billing of the installation location, thus emphasizing the importance of modelling Step 1. Under the current PV regulations and market conditions, (i) net PV exports are not compensated in either country, and (ii) retail electricity prices are fixed throughout the day.[22] For these reasons, there is no incentive for net PV exports, and the value of PV self-consumption is the same irrespective of the time of the day. Therefore, the aim of the battery charging/discharging strategy was modelled to charge the battery as soon as PV generation was higher than electricity demand, and discharge it as soon as PV generation was lower than demand. In other words, battery storage targeted maximising PV self-consumption, thus minimising grid import (as previously modelled in ref. [31]). 
Chatzisideris M.D., Ohms P.K., Espinosa N., Krebs F.C., Laurent A., 2019. Economic and environmental performances of organic photovoltaics with battery storage for residential self-consumption. Applied Energy 256, 113977, 1-13. DOI: https://doi.org/10.1016/j.apenergy.2019.113977

The modelling choice of battery technology was made based on its relevance to PV applications and availability of cost and life cycle inventory data (see the insightful review of battery technologies by Stenzel et al. [40]). A lithium-ion manganese oxide $\left(\mathrm{LiMn}_{2} \mathrm{O}_{4}-\mathrm{LMO}\right)$ battery, which fulfils both criteria of relevance and data availability, was selected based on the Batt-DB battery database [40,41]. This battery type benefits from sufficient data, allowing the construction of a full life cycle inventory, as that available in the ecoinvent database [42] (see Section 3.5.2). For the simulation of the electricity flows of an OPV system with battery storage, the depth of discharge (DoD) and charging/discharging efficiency values were assumed and modelled based on available data - see Table 2 .

Regarding the lifetime of the battery, it is common to distinguish between cyclic and calendric aging processes for battery degradation.[43] To describe the cyclic aging of the battery, which is caused by charging and discharging cycles, the full equivalent cycles (FEC) per year were calculated according to the study by Hesse et al. [43] This enabled the calculation of the cycle lifetime of the battery (expressed in years) as the ratio of the cycle lifetime (expressed in cycles) to the FEC.[41] Finally, to determine the lifetime of the battery, the minimum value between the cycle lifetime and the calendar lifetime was taken, thus allowing the calculation of required battery replacements over a 20 -year system lifetime.

Table 2. Battery systems costs and technical parameters for median and optimistic scenarios, along with prospective cost reduction estimates.

\begin{tabular}{llll}
\hline Cost and technical data & $\begin{array}{l}\text { Median scenario } \\
{[41]}\end{array}$ & $\begin{array}{l}\text { Optimistic scenario } \\
{[41], \mathrm{a}}\end{array}$ & $\begin{array}{l}\text { Prospective cost } \\
\text { reductions } 10 \%- \\
\mathbf{9 0 \%}\end{array}$ \\
\hline Storage capacity cost & $238 € / \mathrm{kWh}$ & $153 € / \mathrm{kWh}$ & $138-15 € / \mathrm{kWh}$ \\
BMS + BoS costs & $500 € / \mathrm{kW}$ & $500 € / \mathrm{kW}$ & $450-50 € / \mathrm{kW}$ \\
O\&M per year & $25 € / \mathrm{kW}$ per year & $20 € / \mathrm{kW}$ per year & $18-2 € / \mathrm{kW}$ per year \\
Charging/discharging efficiency & $94 \%$ & $98.25 \%$ & $98.25 \%$ \\
Cycle lifetime at $80 \%$ DoD & 1500 & 5000 & 5000 \\
Calendar lifetime & 10 years & 15 years & 15 years
\end{tabular}

${ }^{a}$ The optimistic scenario was defined by selecting the best value for each parameter as reported in ref. [41].

\subsection{Economic modelling: coupling with battery storage}

To evaluate the investment profitability of the OPV-only system installed for self-consumption (System A in Figure 2), the modelling steps 3-5 (see Figure 1) were followed as described in ref. [22]. In summary, in Step 3, gross electricity bill savings (i.e. excluding OPV system costs) were calculated for a Danish and a Greek residential electricity consumer $(4000 \mathrm{kWh} /$ year) over the 20 -year investment period. The savings were calculated as the difference in the electricity bill between a household without an OPV installation (baseline electricity costs) and the same household with an OPV system for self-consumption. In Step 4, the OPV system costs were calculated for an 'industrial-scale' OPV system with a 9.8\% module efficiency (combining assumed $98 \%$ fill factor and 10\% cell efficiency; see Table 1) and a 10-year lifetime assuming industrial-scale manufacturing settings [16], as reported in Table 1. In Step 5, the profitability of investing in an OPV system 
Chatzisideris M.D., Ohms P.K., Espinosa N., Krebs F.C., Laurent A., 2019. Economic and environmental performances of organic photovoltaics with battery storage for residential self-consumption. Applied Energy 256, 113977, 1-13. DOI: https://doi.org/10.1016/j.apenergy.2019.113977

was evaluated using the Net Present Value (NPV) method by netting (i) the present value of the annual electricity bill savings (as calculated in Step 3), and (ii) the upfront capital cost of acquiring and installing the OPV system. To determine the capacity size of the OPV battery systems, the NPV of all possible systems with $1-10 \mathrm{kWp}$ OPV and 1-10kWh battery capacities (with steps of $1 \mathrm{kWp}$ and $1 \mathrm{kWh}$ ) were calculated in Step 4. Such ranges of PV and battery capacities are generally considered suitable for residential-scale PV systems.[9] The system that achieved the highest NPV result was determined as the optimal OPV-battery investment solution, also giving the cost-optimal size PV and battery capacities.

One of the focus areas in this study was the integration of battery storage into the economic modelling. Thus, to evaluate the investment profitability of the OPV-battery system (System B in Figure 2), the total OPVbattery system costs were calculated as the sum of the OPV costs and the battery system costs. The battery system costs were calculated as the sum of the battery storage capacity costs (expressed in $€ / \mathrm{kWh}$ ) and the battery power capacity costs (expressed in $€ / \mathrm{kW}$ ), as shown in Table 2 . More specifically, battery power capacity costs comprised battery management system (BMS), balance of system (BoS) and lifetime operation and maintenance (O\&M) costs. The battery power capacity depends on the battery converter capacity, and it was therefore calculated based on the 'minimum required battery converter' approach by Weniger et al. [39]

For the modelling of the battery storage costs, two cost scenarios were considered in this study: a 'median' and an 'optimistic' (reported in Table 2). The 'median' scenario was considered to represent the average techno/economic performance of LMO batteries. For that purpose, the median values of the technical and cost parameters were used based on the comprehensive battery database Batt-DB reported in ref. [41]. The 'optimistic' scenario was defined to account for near-term cost reductions and performance improvements (using a similar approach to ref. [44]). For the optimistic scenario, the best of three values (i.e. first quartile, median and third quartile values, as reported in ref. [41]) was selected for each of the considered battery parameters of Table 2 .

Because battery technologies are rapidly evolving, different types of batteries may also be used in the context of the study. Therefore, as sensitivity analysis for the economic assessment, the base case battery technology (i.e. LMO) was complemented with the testing of seven other battery technologies for the investment profitability of the OPV-battery system thanks to their available documentation in the battery database Batt-DB [41]: valve regulated lead acid (VRLA), lithium titanate (LTO), lithium iron phosphate (LFP), nickel manganese cobalt (NMC), nickel cobalt aluminium oxide (NCA), sodium nickel chloride $(\mathrm{NaNiCl})$ and vanadium redox-flow (VRFB).

\subsection{Environmental modelling}

In Step 6 of the modelling framework (Fig. 1), the environmental performance of OPV systems installed for self-consumption was assessed by conducting an LCA study according to the ISO 14040/14044 standards.[26,27]

\subsubsection{Goal and scope of the LCA}

The LCA study focuses on comparing three systems of electricity supply to a house to identify which system is associated with the lowest environmental impacts, as illustrated in Figure 2: (i) electricity import from the grid (baseline system; no OPV installed); (ii) self-consumption based on an OPV-only system; and (iii) self-consumption based on an OPV-battery system. In addition, the LCA study was used to investigate the effect of upscaling from a pilot-scale to an industrial-scale setting with technological advances (see Table 1) on the environmental performance of OPV technologies. 
Chatzisideris M.D., Ohms P.K., Espinosa N., Krebs F.C., Laurent A., 2019. Economic and environmental performances of organic photovoltaics with battery storage for residential self-consumption. Applied Energy 256, 113977, 1-13. DOI: https://doi.org/10.1016/j.apenergy.2019.113977

The functional unit of the LCA, which provides the quantitative basis for comparison of the three systems, was defined as the provision of $1 \mathrm{kWh}$ of electricity to a typical one-family Danish/Greek house with an assumed electricity demand of $4000 \mathrm{kWh}$ /year over a 20 -year period. The system boundaries of the LCA study covered the entire life cycle of the OPV systems, i.e. from raw material extraction through manufacturing, operation up to the end of life, as recommended by previous reviews and guidance.[25,27] From an LCA modelling perspective, a consequential modelling was adopted where OPV exports were treated as by-products of the OPV system, and to account for the associated environmental impacts, system expansion was applied according to the requirements from the ISO standards.[27] Overall, the environmental profiles of Systems A and B were calculated as a mix of grid imports and OPV self-consumption (for System A) or OPVbattery self-consumption (System B), for which the balance was indicated by the calculated electricity flows (see Section 3.2). The life cycle impact assessment (LCIA) phase was performed using the International Reference Life Cycle Data System (ILCD) LCIA method v.1.10 (June 2017, [45]) covering a total of 15 environmental impact categories (see Table S1, ESI).

\subsubsection{Data collection and system modelling}

An OPV LCA model was developed in SimaPro 8.4 [46], relying on the ecoinvent database v.3.3 (consequential) for background process modelling.[47] To model the OPV systems, three key components are distinguished: the OPV modules; the balance of system components $(\mathrm{BoS})$ including the inverter, wiring and support structure; and an LMO battery pack (or another type of battery for sensitivity analysis; see Section 3.5.3. Life cycle inventory (LCI) data for the OPV modules were adapted from Espinosa et al. [28], who described an actual pilot-scale production line of OPV with $1 \%$ efficiency and 1.5-year lifetime. For the disposal stage, the valuable materials (i.e. Ag and PET) were assumed to be recycled, and the remaining parts incinerated with energy recovery in both Greece and Denmark (based on ref. [28]; see modelling details in Supplementary Methods, ESI). The BoS and batteries were modelled by adapting available LCI from the ecoinvent database and assuming similar support structures as PV roof installations. Further details on the documentation of the model, including sources of uncertainties, are available in Supplementary Methods (ESI); detailed LCI information for each modelled process is provided in Tables S2-S27 (ESI).

Consistent with the adopted consequential modelling approach, long-term marginal electricity grid mixes for GR and DK as reported under ecoinvent 3.3 database $[48,49]$ were used as default for the modelling of electricity imports and exports from/to the grid over the 20-year system lifetime (see Supplementary Methods, ESI). The identification of the long-term marginal grid mix is however associated with important uncertainties as relying on long-term projections about the future installation of additional energy capacity.[50,51] Two other electricity mixes were therefore considered as sensitivity analysis to explore the influence of the grid mix compositions on each of the two countries: alternative compositions of the long-term marginal grid mixes and average grid mixes were thus considered (see details in Supplementary Methods and Figure S1, ESI).

\subsubsection{Basis for uncertainty and sensitivity analyses}

A number of assumptions and uncertainties lies in the building of the LCA model and the eventual impact assessment. Sensitivity analyses were therefore conducted to quantify the influence of those sources of uncertainties on the results and conclusions. These are documented in Table 3, with background details available in Supplementary Methods. 
Chatzisideris M.D., Ohms P.K., Espinosa N., Krebs F.C., Laurent A., 2019. Economic and environmental performances of organic photovoltaics with battery storage for residential self-consumption. Applied Energy 256, 113977, 1-13. DOI: https://doi.org/10.1016/j.apenergy.2019.113977

Table 3. Sensitivity scenarios considered to test the robustness of environmental impact results and identify influential parameters. Sensitivity analysis is only applied at industrial scale for all three considered systems see Figure 2. Background documentation on modelling of scenarios in Supplementary Methods, ESI.

\begin{tabular}{|c|c|c|}
\hline & Rationale & $\begin{array}{l}\text { Sensitivity scenarios considered } \\
\text { (baseline recalled with *) }\end{array}$ \\
\hline Battery types & $\begin{array}{l}\text { Uncertainties on the type of } \\
\text { technology retained (fast- } \\
\text { developing field) }\end{array}$ & $\begin{array}{l}\text { - LMO battery* } \\
\text { - NaNiCl battery }\end{array}$ \\
\hline $\begin{array}{l}\text { Electricity grid } \\
\text { mixes }\end{array}$ & $\begin{array}{l}\text { Difficulties in assessing mix of } \\
\text { marginal technologies }+ \\
\text { modelling choices }\end{array}$ & $\begin{array}{l}\text { - Mix of long-term marginal } \\
\text { technologies* } \\
\text { - Alternative mix of long-term marginal } \\
\text { technologies } \\
\text { - Average mix of energy sources }\end{array}$ \\
\hline $\begin{array}{l}\text { Method of impact } \\
\text { assessment }\end{array}$ & $\begin{array}{l}\text { Uncertainties in the different } \\
\text { models behind the life cycle } \\
\text { impact assessment methods }\end{array}$ & $\begin{array}{l}\text { - ILCD LCIA (v. } 1.10 \text { [45]) } \\
\text { - } \operatorname{ReCiPe~} 2016 \text { [52] }\end{array}$ \\
\hline
\end{tabular}

\section{Results and discussion}

\subsection{Economic analysis of OPV systems with battery storage}

\subsubsection{Investment profitability: effect of battery storage}

Table 4 summarises the profitability of investing in OPV-only and OPV-battery systems for selfconsumption at households in Denmark and Greece. For Denmark, the optimal OPV-only investment was achieved by a $1 \mathrm{kWp}$ system with $1216 € \mathrm{NPV}$ reaching a $5.5 \%$ electricity bill reduction. For Greece, the optimal OPV-only investment was achieved by a $1 \mathrm{kWp}$ system with $1164 €$ NPV reaching an $8.9 \%$ electricity bill reduction. Investing in OPV-battery systems was found financially unattractive compared to OPV-only systems, under the median and optimistic LMO battery cost scenarios, as shown in Table 4. Under the median battery scenario, investing in an OPV-battery system did not offer any profit for either country. Under the optimistic battery scenario, even though the OPV-battery systems offered profitable investments in absolute terms, their profits were lower than the profits from investing in OPV-only systems (Table 4). Under that scenario, for Denmark, the optimal OPV-battery investment was achieved by a $2 \mathrm{kWp} / 3 \mathrm{kWh}$ (i.e. OPV and effective battery storage capacities, respectively) system with $760 € \mathrm{NPV}$, reaching a $3.5 \%$ electricity bill reduction thus offering a less profitable investment compared to the $1216 € \mathrm{NPV}$ achieved by an OPV-only system. Similarly for Greece, assuming an hourly-based net-metering scheme, the optimal OPV-battery investment was achieved by a $2 \mathrm{kWp} / 3 \mathrm{kWh}$ system with $1145 € \mathrm{NPV}$, reaching an $8.8 \%$ electricity bill reduction. Such an OPV-battery system offered a less profitable investment, albeit marginally close, compared to the $1164 €$ NPV achieved by an OPV-only system. These results show that there is no financial motivation for adding battery storage to OPV systems for self-consumption in the cases of Denmark and Greece, under the investigated scenarios of OPV and battery costs. This remains valid in the majority of cases, where other battery technologies (alternative to LMO) are used - see Table S28 (ESI). These results therefore demonstrate 
Chatzisideris M.D., Ohms P.K., Espinosa N., Krebs F.C., Laurent A., 2019. Economic and environmental performances of organic photovoltaics with battery storage for residential self-consumption. Applied Energy 256, 113977, 1-13. DOI: https://doi.org/10.1016/j.apenergy.2019.113977

that further battery cost reductions are needed before battery storage can offer financial benefits to OPV systems for self-consumption.

To the best of our knowledge, existing literature lacks studies assessing the economic performance of OPV systems with battery storage. However, our findings are consistent with those from Quoilin et al. [44], who found that a PV battery system installed in Germany could not offer a profitable investment unless further battery cost reductions were achieved in the future. This may suggest that the conclusions reached for Denmark and Greece may be generalised to other countries, given the current technical and market landscapes of batteries. However, with the fast technical development of battery technologies such conclusions may be altered in the near future (see Section 4.1.2).

\subsubsection{Prospective outlook of battery cost reductions}

From the results in Section 4.1.1, it can be envisioned that future battery cost reductions may alter the investment profitability of OPV-battery systems. A sensitivity analysis carried out to get insights into this matter produced additional investment profitability results of OPV-battery systems for a range of $10 \%$ to $90 \%$ battery cost reductions assuming that the cost reductions were divided equally among the battery cost components (Table 2). Since this assumption of equal division of cost reductions is a simplified approach, the sensitivity analysis results should be interpreted with caution. Further research is required to determine more accurate estimations of battery cost reductions.

Table 4 indicates that $30 \%$ and $10 \%$ battery cost reductions would be required in Denmark and Greece, respectively, so that OPV-battery systems could offer bigger investment profits than OPV-only systems. More specifically, for Denmark, based on a $30 \%$ battery cost reduction, the optimal OPV-battery investment was achieved by a $2 \mathrm{kWp} / 4 \mathrm{kWh}$ system with $1361 € \mathrm{NPV}$ reaching a $6.2 \%$ electricity bill reduction. For Greece, based on a $10 \%$ battery cost reduction, the optimal OPV-battery investment was achieved by a $2 \mathrm{kWp} / 3 \mathrm{kWh}$ system with $1339 €$ NPV reaching a $10.2 \%$ electricity bill reduction.

Further battery cost reductions between $40 \%$ (DK) or $20 \%$ (GR) and $90 \%$ could achieve larger electricity bill reductions, but they might not be sufficiently attractive (see Table 4). For example, for Denmark, battery cost reductions in the range $40 \%$ to $90 \%$ could help OPV battery systems to achieve electricity bill reduction between $7.2 \%$ and $12.7 \%$ (ca. $24 \%$ can be achieved for Greece under $90 \%$ cuts). These results suggest that even with major battery cost reductions, the benefits for OPV-battery systems may be limited in most countries. As a result, further OPV cost reductions might be necessary before battery storage can offer significant benefits - see exploration in Section 4.1.3. 
Chatzisideris M.D., Ohms P.K., Espinosa N., Krebs F.C., Laurent A., 2019. Economic and environmental performances of organic photovoltaics with battery storage for residential self-consumption. Applied Energy 256, 113977, 1-13. DOI: https://doi.org/10.1016/j.apenergy.2019.113977

Table 4. Investment profitability of OPV-only (System A) and OPV-battery (System B) systems installed for self-consumption at houses in Denmark and Greece with a typical electricity demand of $4000 \mathrm{kWh} / \mathrm{y}$ (see Figure 2). Electricity bill reduction results were calculated compared to the baseline system in which there is no OPV system installed.

\begin{tabular}{|c|c|c|c|c|c|c|c|c|c|c|}
\hline \multirow[t]{2}{*}{ System setup } & \multirow{2}{*}{\multicolumn{2}{|c|}{$\begin{array}{l}\text { Battery system } \\
\text { cost scenario }\end{array}$}} & \multicolumn{4}{|l|}{ Denmark } & \multicolumn{4}{|l|}{ Greece } \\
\hline & & & $\begin{array}{l}\text { NPV of } \\
\text { investment }\end{array}$ & $\begin{array}{l}\text { Electricity } \\
\text { bill } \\
\text { reduction }\end{array}$ & $\begin{array}{l}\text { OPV } \\
\text { capacity } \\
{[\mathrm{kWp}]}\end{array}$ & $\begin{array}{l}\text { Effective } \\
\text { battery storage } \\
\text { capacity }[\mathrm{kWh}]\end{array}$ & $\begin{array}{l}\text { NPV of } \\
\text { investment }\end{array}$ & $\begin{array}{l}\text { Electricity } \\
\text { bill } \\
\text { reduction }\end{array}$ & $\begin{array}{l}\mathrm{OPV} \\
\text { capacity } \\
{[\mathrm{kWp}]}\end{array}$ & $\begin{array}{l}\text { Effective } \\
\text { battery storage } \\
\text { capacity }[\mathrm{kWh}]\end{array}$ \\
\hline OPV-only & - & & $€ 1,216$ & $5.5 \%$ & 1 & - & $€ 1,164$ & $8.9 \%$ & 1 & - \\
\hline \multirow[t]{11}{*}{ OPV-battery } & median & & $€-476$ & $-2.2 \%$ & 2 & 1 & $€-594$ & $-4.5 \%$ & 2 & 3 \\
\hline & optimistic & & $€ 760$ & $3.5 \%$ & 2 & 3 & $€ 1,145$ & $8.8 \%$ & 2 & 3 \\
\hline & prospective & $10 \%$ & $€ 953$ & $4.3 \%$ & 2 & 3 & $€ 1,339$ & $10.2 \%$ & 2 & 3 \\
\hline & battery cost & $20 \%$ & $€ 1,147$ & $5.2 \%$ & 2 & 3 & $€ 1,533$ & $11.7 \%$ & 2 & 3 \\
\hline & reductions & $30 \%$ & $€ 1,361$ & $6.2 \%$ & 2 & 4 & $€ 1,732$ & $13.2 \%$ & 2 & 4 \\
\hline & & $40 \%$ & $€ 1,581$ & $7.2 \%$ & 2 & 4 & $€ 1,951$ & $14.9 \%$ & 2 & 4 \\
\hline & & $50 \%$ & $€ 1,800$ & $8.2 \%$ & 2 & 4 & $€ 2,171$ & $16.6 \%$ & 2 & 4 \\
\hline & & $60 \%$ & $€ 2,019$ & $9.2 \%$ & 2 & 4 & $€ 2,390$ & $18.3 \%$ & 2 & 4 \\
\hline & & $70 \%$ & $€ 2,239$ & $10.2 \%$ & 2 & 5 & $€ 2,617$ & $20.0 \%$ & 2 & 5 \\
\hline & & $80 \%$ & $€ 2,484$ & $11.3 \%$ & 2 & 5 & $€ 2,861$ & $21.9 \%$ & 2 & 5 \\
\hline & & $90 \%$ & $€ 2,794$ & $12.7 \%$ & 3 & 8 & $€ 3,106$ & $23.7 \%$ & 2 & 5 \\
\hline
\end{tabular}


Chatzisideris M.D., Ohms P.K., Espinosa N., Krebs F.C., Laurent A., 2019. Economic and environmental performances of organic photovoltaics with battery storage for residential self-consumption. Applied Energy 256, 113977, 1-13. DOI: https://doi.org/10.1016/j.apenergy.2019.113977

\subsubsection{Target costing for OPV with battery storage}

To explore to what extent OPV costs need to be reduced to bring sufficient benefits to OPV-battery systems (e.g. a specific investment profit), a target costing approach was performed taking the same approach as in ref. [22] in the context of OPV-only systems for self-consumption.

Figure 3 plots OPV target costs as a function of investment profits delivered by OPV-only and OPVbattery systems installed for self-consumption in Denmark and Greece (considering the optimistic battery scenario). It reveals that there is an OPV cost threshold below which OPV-battery systems are more costeffective than OPV-only systems. This OPV cost threshold is found at the intersection of the OPV-only and OPV-battery curves: $0.9 € / \mathrm{Wp}$ for Denmark (point "DK-1" in Figure 3) and 1.6€/Wp for Greece (point "GR1 " in Figure 3). In the case of Greece, this $1.6 € / \mathrm{Wp}$ cost level is marginally lower than the industrial-scale cost scenario of $1.62 € / \mathrm{Wp}$. This indicates that in the case of Greece, unless industrial-scale OPV systems are coupled with battery storage, they are not cost-optimally designed. Therefore, coupling OPV systems with battery storage is essential for OPV technologies assuming that OPV technology costs decline in the course of time. This finding is in line with a previous study by Weniger et al. [9], where the authors showed that PVbattery systems will offer the most cost-effective solution compared to PV-only systems if PV and battery costs continue to decrease according to projections.

Moreover, to investigate the influence of prospective battery cost reductions on the OPV target costs, the OPV-battery cost curve for Denmark was recalculated assuming a 30\% battery cost reduction (Figure 3 ). A 30\% battery cost reduction shifted the OPV-battery curve higher, thus increasing the cost threshold from 0.9 $€ / \mathrm{Wp}$ to $1.75 € / \mathrm{Wp}$ (i.e. shift from "DK1" to "DK2" in Fig. 3). This result indicates that, depending on how fast battery costs decline in the future, sufficient battery cost reductions may be achieved before OPV-battery systems become more cost-effective than OPV-only systems, hence requiring OPV technology developers to consider integration of battery storage sooner than expected.

To further support OPV technology developers in determining OPV target costs, it is necessary to determine what level of investment profit or electricity bill reduction would be sufficiently attractive for electricity consumers to invest in OPV and battery systems? To address this question, more insights into consumer behaviour may be useful. Unfortunately, such studies are limited in the literature. To the authors' knowledge, only one relevant study by Klingler [37] has investigated consumer preferences in the context of PV self-consumption. In that study, the market diffusion of batteries was modelled for PV self-consumption in Germany, leading the author to argue that 'innovators' (i.e. market research term referring to consumers that adopt a technology during its initial stages) were ready to pay for a battery on average at $60 \%$ higher price than its actual benefit to PV self-consumption.[37] These findings therefore suggest that 'innovators' and other early adopter-consumer groups could make OPV enter the PV self-consumption market during its early stages, even though OPV systems would not yet be economically-competitive. Unfortunately, the approach presented in Klingler [37] cannot be used further in our study due to scoping differences between the two studies. However, more studies of this type should be initiated to evaluate consumer preferences and combine the results with the target costing approach presented in this study to inform and aid OPV technology developers derive OPV target costs. 


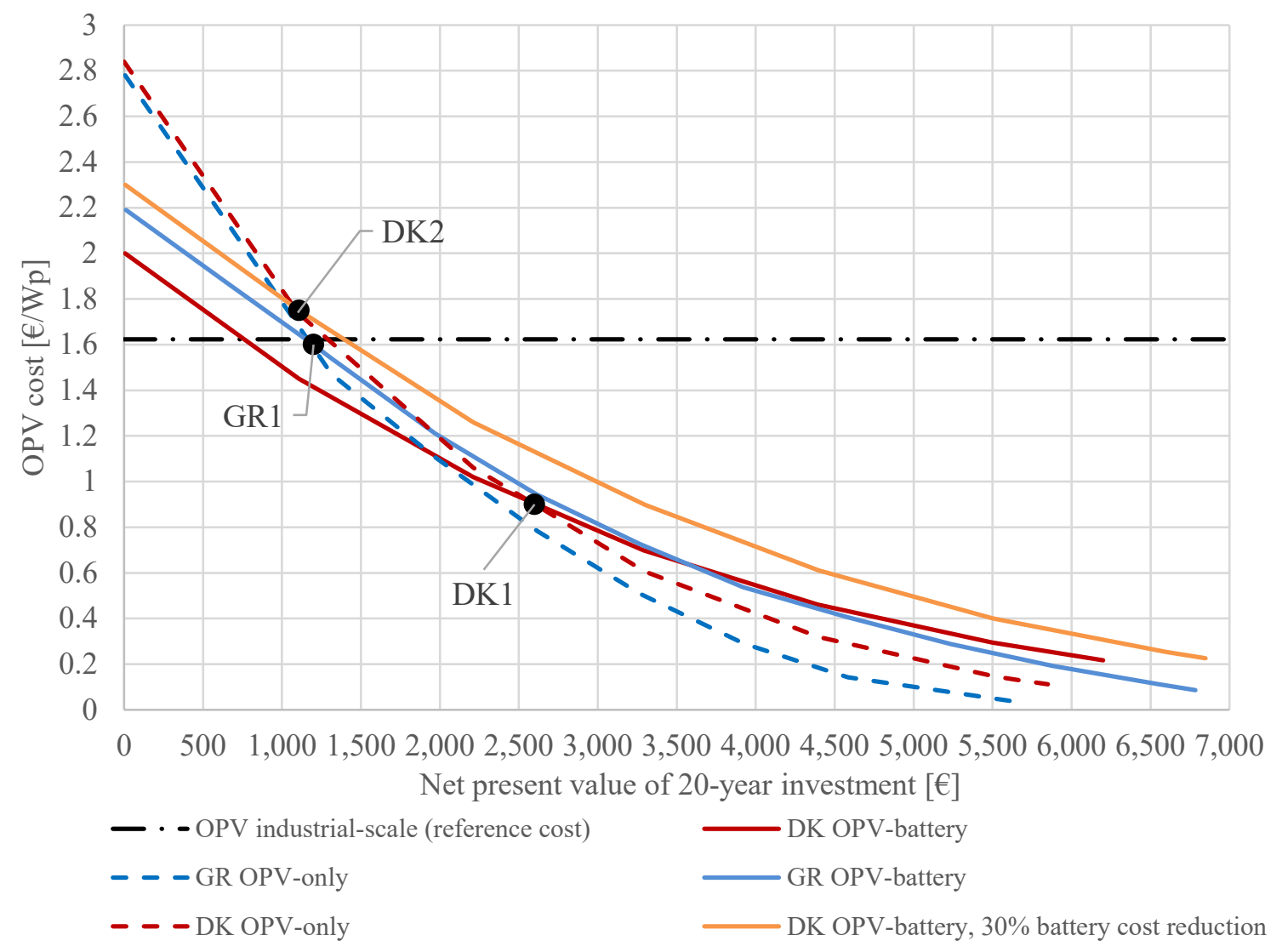

Figure 3. Required OPV target costs as a function of the desired profits. Profits relate to gains from investing in OPV-only (dashed curves) and OPV-battery systems (thick curves) for self-consumption in Denmark (red/orange curves) and Greece (blue curves) over a 20 -year period.

\subsection{Environmental impacts of electricity generation from $O P V$}

\subsubsection{Comparing electricity generation at pilot- and industrial scales}

As Figure 4A illustrates, the industrial-scale OPV system in Denmark (9.8\% efficiency, 10-year lifetime) logically shows lower environmental impacts compared to the pilot-scale OPV system (1\% efficiency, 1.5-year lifetime) in most impact categories, with impact indicator scores for the industrial OPV systems ranging from $4 \%$ to $56 \%$ of the pilot-scale system and saved impacts occurring for particulate matter and acidification (detailed impact results in Table S29, ESI). These observations result from the drastic reduction in the required area of OPV modules from $1330 \mathrm{~m}^{2}$ to $20.4 \mathrm{~m}^{2}$ per $\mathrm{kWp}$ over the 20 -year lifetime when upscaling from pilot- to industrial scale. Scaling the OPV modules from pilot-scale to industrial-scale leads to a markedly lower amount of Ag used and thereby lower impacts related to the OPV modules. While the OPV modules are scaled, the BoS (i.e. inverters, mounting system and electric wiring) is not. Hence, the recovery of metals from electronics scrap is thus, given a larger relative influence, reversing the impact to saved environmental impacts for the industry-scale system (e.g. terrestrial acidification in Fig. 4A). A few impact categories also showed increases, i.e. human toxicity (non-cancer effects), ionizing radiation (human health) and water resource depletion, due to less crediting from the recovery of $\mathrm{Ag}$ (consequence of less $\mathrm{Ag}$ present in the OPV modules in the industrial scale than in the pilot-scale, hence less benefits from $\mathrm{Ag}$ recycling). More details about the observed trends from Figure 4 are available in Table S30 (ESI). 
Chatzisideris M.D., Ohms P.K., Espinosa N., Krebs F.C., Laurent A., 2019. Economic and environmental performances of organic photovoltaics with battery storage for residential self-consumption. Applied Energy 256, 113977, 1-13. DOI: https://doi.org/10.1016/j.apenergy.2019.113977

$\mathbf{A}$

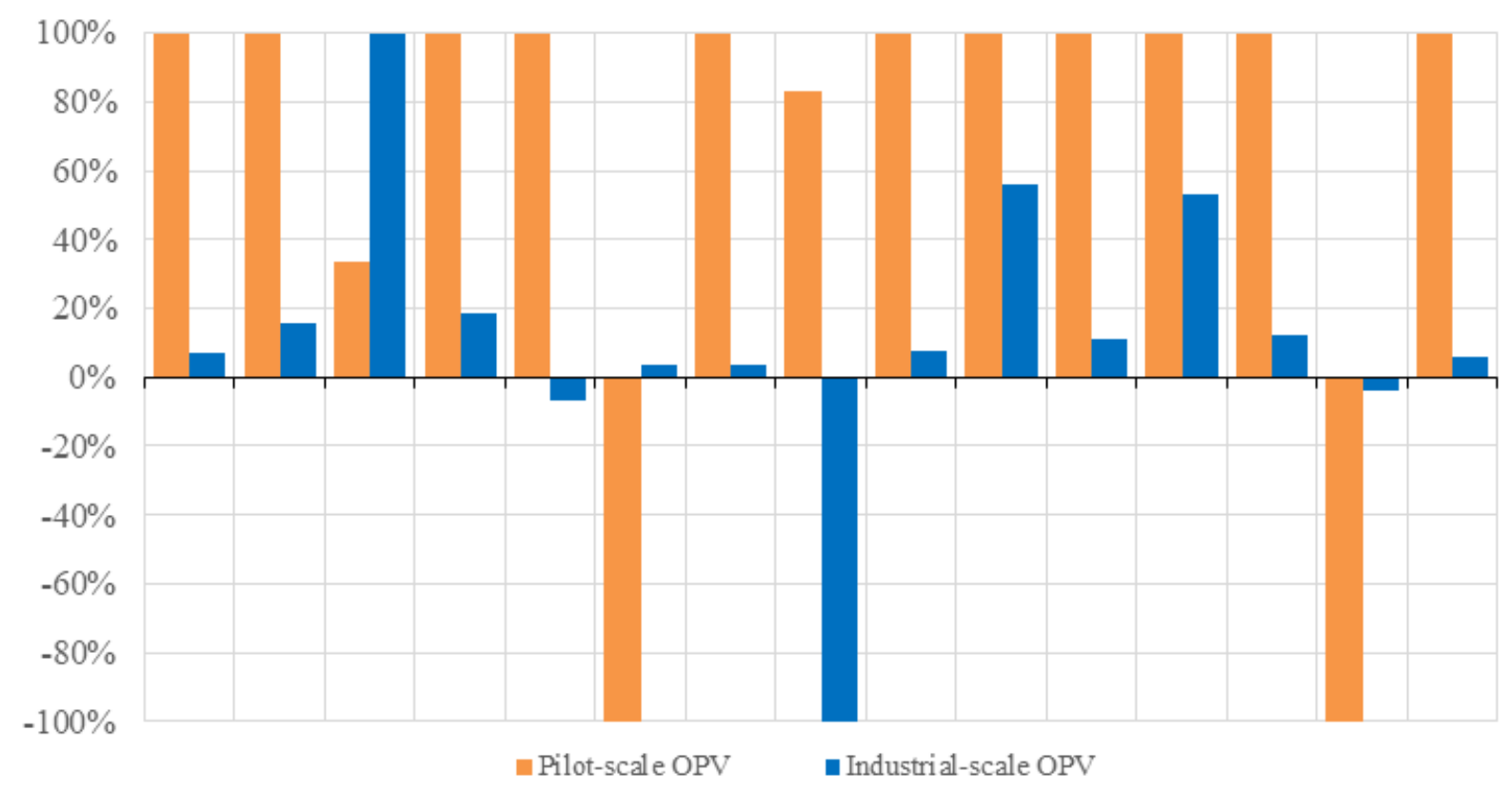

B

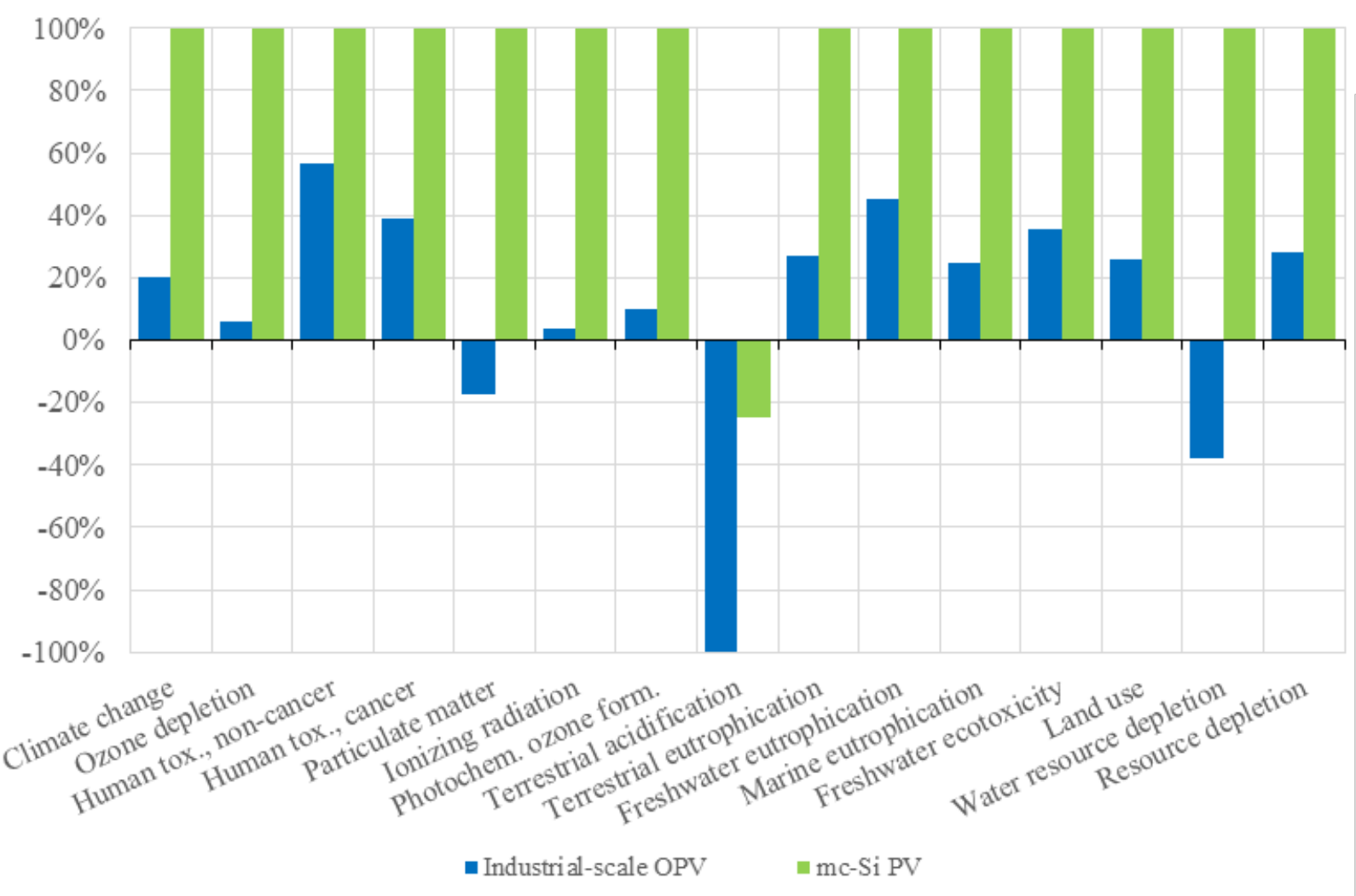

Figure 4. Comparison of the environmental profiles of (A) the pilot-scale OPV system (1\% efficiency, 1.5year lifetime) $v s$. the industrial-scale OPV system (9.8\% efficiency, 10-year lifetime); and (B) the industrialscale OPV system vs. a multi-cristalline (mc) Si PV system (ecoinvent LCI database). Normalised environmental impacts are shown for OPV systems installed in Denmark (normalisation by maximum result per impact category). LCI data for mc-Si PV systems from ecoinvent database. Detailed results in Table S29 (ESI). 
Chatzisideris M.D., Ohms P.K., Espinosa N., Krebs F.C., Laurent A., 2019. Economic and environmental performances of organic photovoltaics with battery storage for residential self-consumption. Applied Energy 256, 113977, 1-13. DOI: https://doi.org/10.1016/j.apenergy.2019.113977

The environmental impacts of OPV systems can be put in perspective with the silicon-based PVs (Si-PV), which constitute a more mature PV technology and thus should be comparable to the industrial-scale OPVsystem. As observed in Figure 4B, the Si-PV system present higher environmental impacts in all categories with indicator scores for the industrial OPV systems ranging from $4 \%$ to $57 \%$ of those of the Si-PV system and saved impacts occurring for particulate matter, acidification and water resource depletion due to crediting from recycling of the inverter and the mounting system. While the inverter and mounting system in the Si-PV system are also recycled, the crediting therein is not sufficient to outweigh the impacts from the production of silicon, copper and aluminium necessary for the PV panel and mounting system. When reading these results, caution should be exerted as the technological assumptions behind the upscaling are based on expert estimates and experiments (Table 1). As OPV technology refinements are made, future studies may therefore show that more conservative estimates would be a better fit for industrial scale scenarios, thus calling for updated assessment of environmental impacts. Yet, in light of Figure 4B results, significant reductions in the anticipated future OPV technology performances would be required to bring the environmental impacts of OPV systems to the same level as mc-Si PV systems. Given current and foreseen OPV technology efficiencies and lifetime performances $[15,53,54]$, this possibility however seems unlikely.

\subsubsection{Main impact drivers within the OPV-only system}

Figure 5 shows the distribution of environmental impacts between the industrial-scale OPV system components. Because of the major reduction in required OPV modules, the contribution of the OPV modules to the total environmental impacts of the system overall decreased significantly in the industrial-scale OPV systems. As a consequence, while the OPV modules are overall the main drivers of the impacts in the pilotscale systems (Table S31, ESI), the BoS (i.e. inverters, mounting system and electric wiring) become the main driver of environmental impacts (see Table S32, ESI). The BoS mainly consists of mature technologies and thus does not benefit from as large upscaling effects as OPV modules when scaling up the entire OPV systems to industrial scale. This is consistent with findings from the review in ref. [25], where the increasing relevance of BoS components is highlighted as PV module technologies continue to develop. These results therefore call for OPV technology developers to integrate the BoS into future eco-design strategies, particularly when OPV module performances tend to reach ca. 10\% efficiency and 10-year lifetime. 


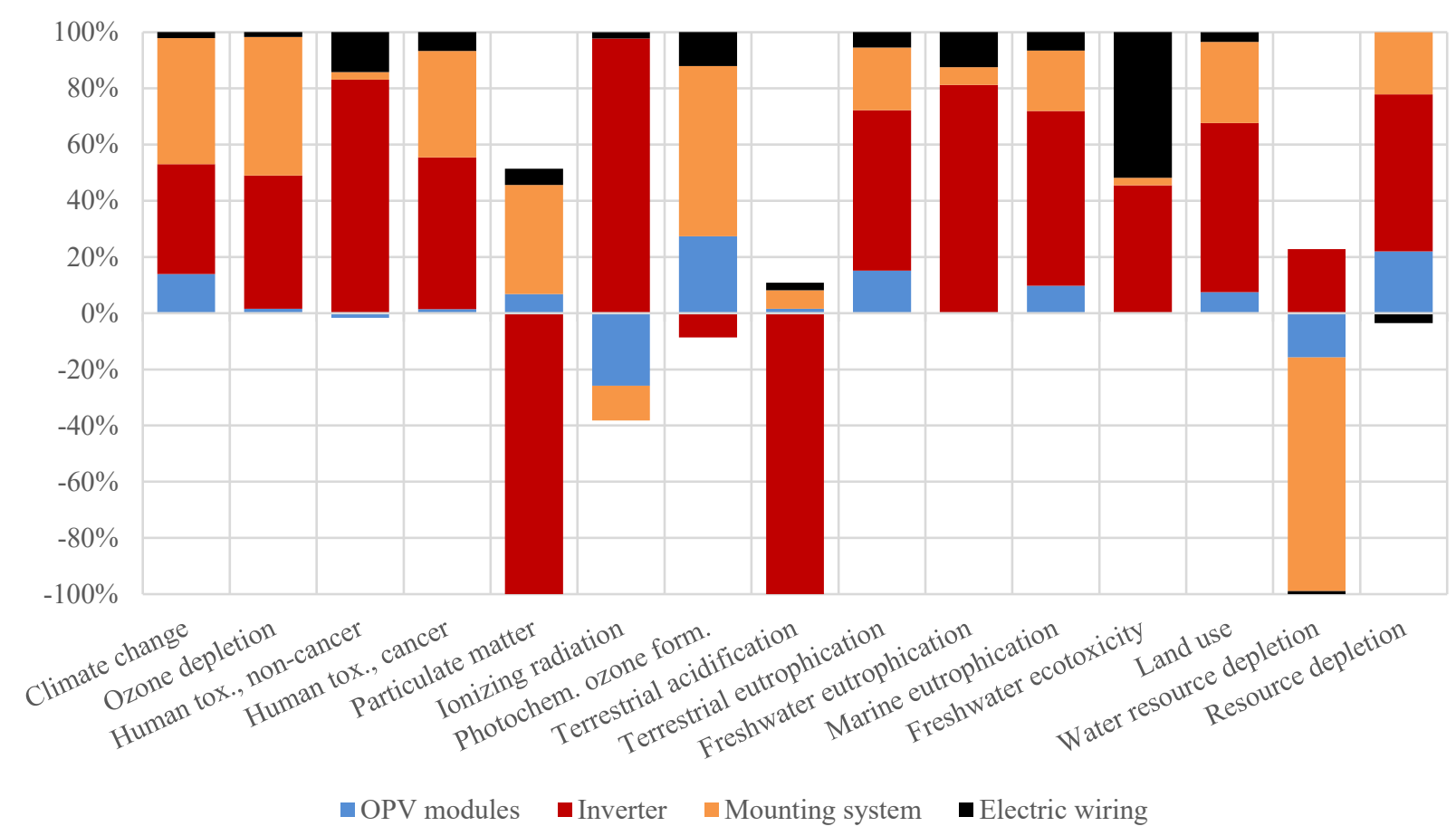

Figure 5. Distribution of environmental impacts from electricity generation from an industrial-scale OPV system installed in Denmark. Similar results are expected for Greece due to manufacturing assumed located in DK (data not shown). Detailed impact scores in Table S32.

\subsection{Environmental performances of electricity self-consumption from OPV systems}

\subsubsection{Comparisons of grid imports, OPV-only, and OPV-battery systems}

As shown in Figures 6A and 6B, electricity supply based on self-consumption from OPV systems caused lower environmental impacts compared to electricity imports from the grid in most impact categories, for both Denmark and Greece (see also Tables S33-S34 for detailed impact scores, ESI). With few exceptions, most impacts decreased by $14-19 \%$ and $26-37 \%$ when moving from grid imports to OPV-only systems in DK and GR, respectively (Figures 6A and 6B). Notable exception is the impact on climate change in Denmark, which shows an increase mainly due to its renewables-based electricity grid mix, which makes grid imports associated with relatively low impacts. The added impacts caused by the OPV production and installation, particularly the mounting system or the silver production, therefore cause the OPV systems (with or without battery) to have higher environmental impacts per functional unit. These findings demonstrate that some environmental impact results are sensitive to the geographical location of the OPV systems (country-specific), in particular the composition of its electricity grid mix (see Section 4.3.2).

The OPV-battery system is observed to outperform the OPV-only system in both Denmark and Greece for most impact categories (with few exceptions for Denmark as mentioned above), with impact reductions ranging $4-21 \%$ and $34-57 \%$, respectively (Figs. 6A and 6B). Because the integration of battery storage allows the increase of the cost-optimal OPV capacity from $1 \mathrm{kWp}$ for the OPV-only system to $2 \mathrm{kWp}$ for the OPVbattery system (in both countries), it enables a larger displacement of grid electricity by OPV generation, and hence avoids occurrences of the associated impacts. An additional reason lies in the difference of environmental impacts between the added OPV capacity and the displaced grid electricity that offsets the 
Chatzisideris M.D., Ohms P.K., Espinosa N., Krebs F.C., Laurent A., 2019. Economic and environmental performances of organic photovoltaics with battery storage for residential self-consumption. Applied Energy 256, 113977, 1-13. DOI: https://doi.org/10.1016/j.apenergy.2019.113977

environmental impacts of the battery storage. Altogether, these findings indicate that the integration of battery storage can contribute to the reduction of the environmental impacts associated with electricity selfconsumption based on OPV systems under three main conditions: (i) the battery costs are low enough to allow the OPV-battery system to be more cost-effective than the OPV-only system, (ii) the capacity of the costoptimal OPV-battery system is larger than that of the OPV-only system, and (iii) the environmental impacts of the battery are low enough to be offset by the difference in environmental impacts between the added OPV capacity and the displaced grid electricity.

These results are consistent with previous studies [31,55,56], which argued that the addition of battery leads to similar or slightly increased impacts when comparing PV-battery and PV-only systems assuming a same PV capacity. They also point out to the importance of carefully considering the PV capacities in such comparisons: while all previous studies have assumed a same PV capacity for both PV-only and PV-battery systems, our study shows that this may not be an appropriate since the addition of a battery to the PV systems means that different PV capacities can provide the same function/service of electricity supply. Future environmental impact assessment studies should therefore integrate this possibility of different PV capacities when defining their scope and modelling their PV systems.

Regardless of this methodological recommendation, it is noteworthy that the modelling of the batteries in the current study is expected to carry important uncertainties as battery technologies evolve rapidly and LCI data are scarce and lag behind updates. [57] The sensitivity analysis made on the battery type did not show that this was a key driver of the environmental performances of the OPV-battery systems (see Figure S2, ESI). However, further research should consider developing life cycle inventory data for a broader range of battery technologies integrating recent technological advances, and re-assess the influence of batteries in OPV selfconsumption systems. 
A
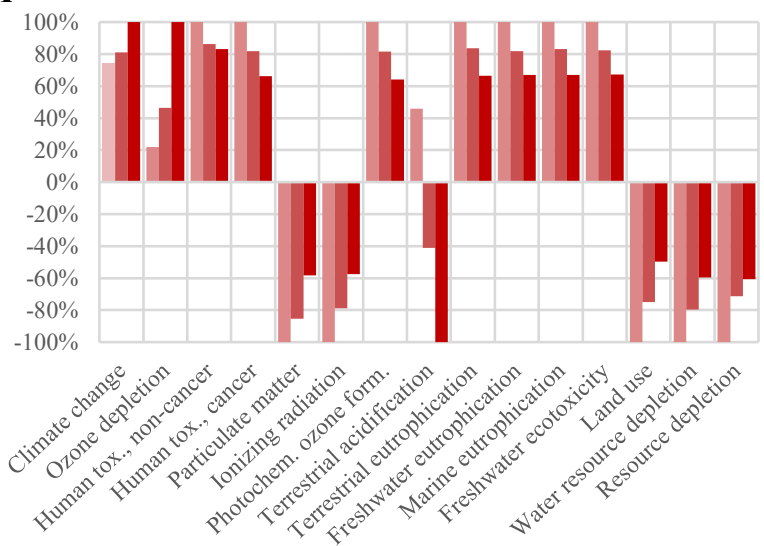

C
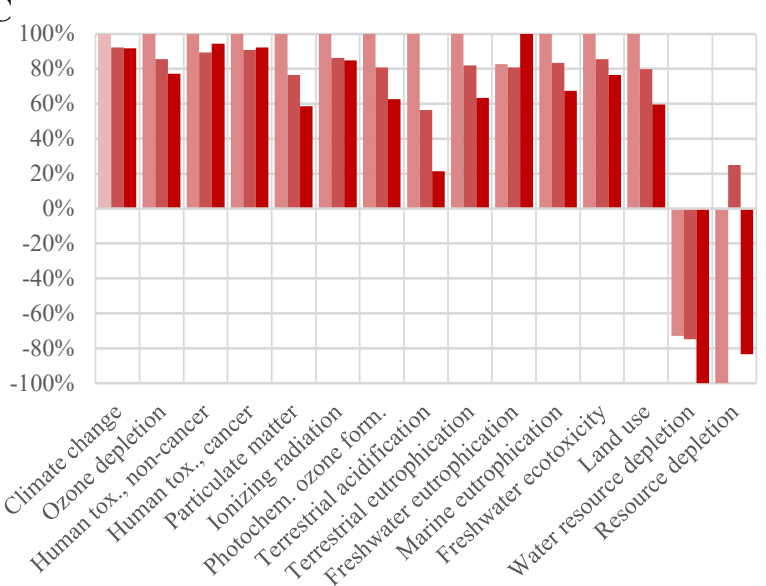

$\mathbf{E}$
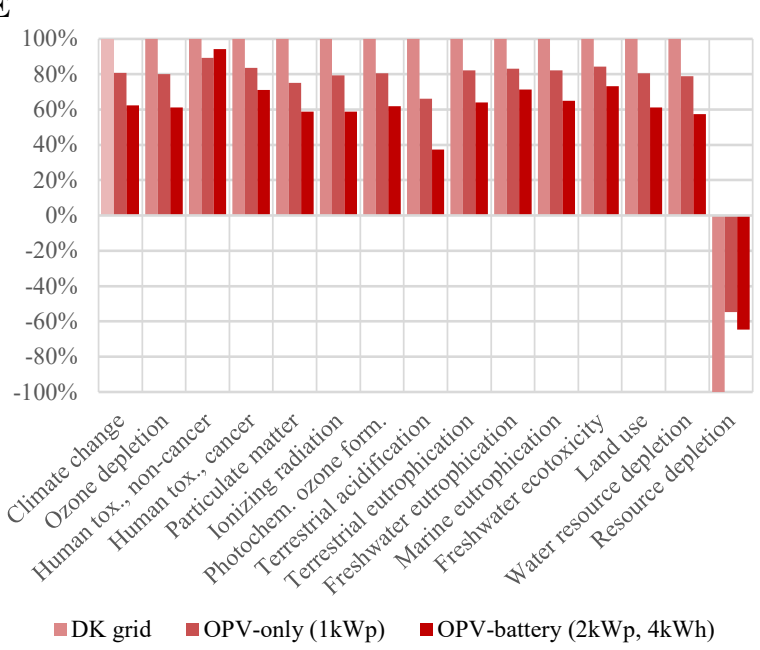

B
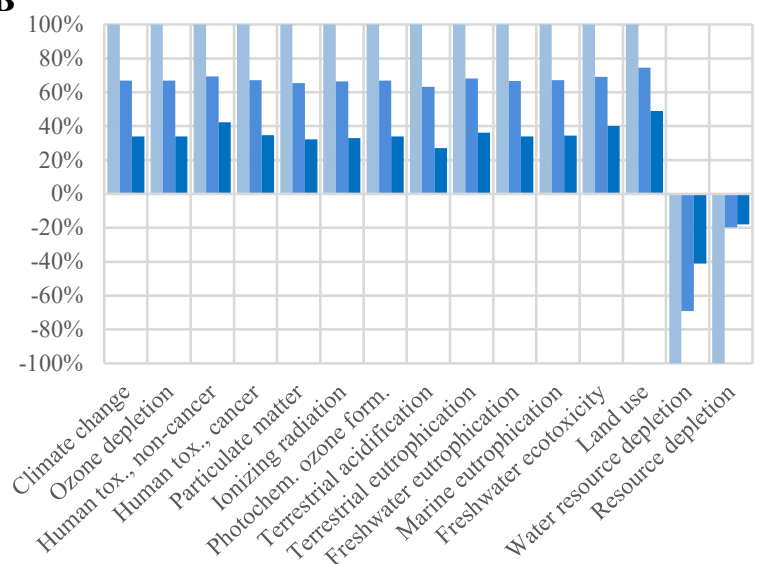

D
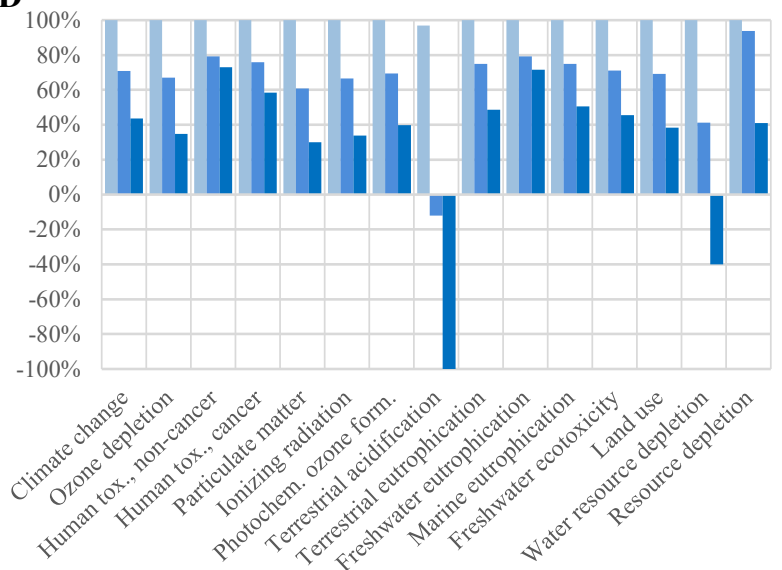

F
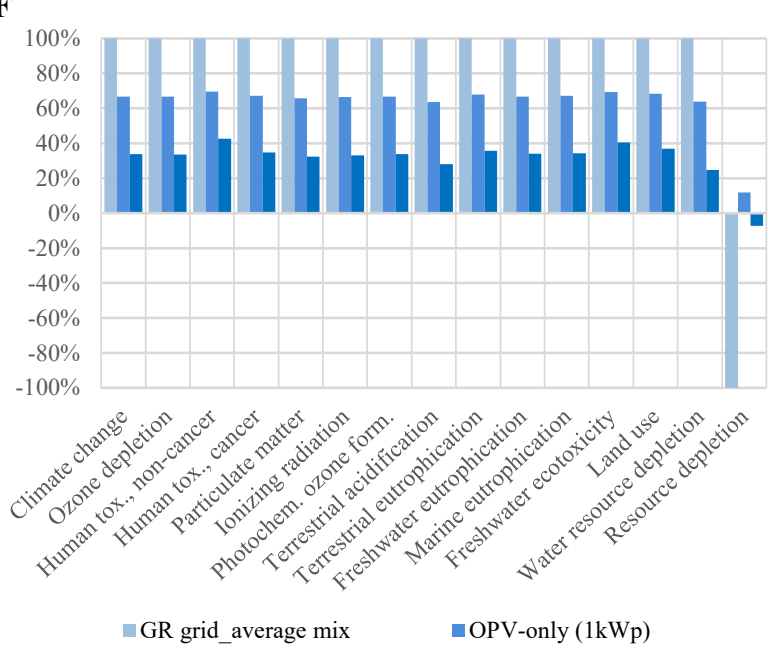

Figure 6. Comparative environmental impacts to supply a typical household electricity demand of $4000 \mathrm{kWh} / \mathrm{y}$ (OPV-battery) in Denmark (red) and Greece (blue). Three systems are compared in each inset: (i) import from electricity grid (DK/GR mix), (ii) self-consumption based on an OPV-only system (OPV-only) and (iii) selfconsumption based on an OPV-battery system. Sensitivity to the grid electricity modelling is illustrated with default long-term marginal mix (6A and 6B), alternative long-term marginal mix (6C and 6D), and average mix (6E and 6F) -see Section 3.5.3 for details. Cost-optimised OPV-only and OPV-battery systems are considered, hence the differences in installed capacities between the two. Impact results are displayed as normalised results (by maximum results per impact category). Detailed impact scores for Figs. 6A and 6B are reported in Tables S33 and S34. 
Chatzisideris M.D., Ohms P.K., Espinosa N., Krebs F.C., Laurent A., 2019. Economic and environmental performances of organic photovoltaics with battery storage for residential self-consumption. Applied Energy 256, 113977, 1-13. DOI: https://doi.org/10.1016/j.apenergy.2019.113977

\subsubsection{Influence of electricity grid composition on environmental performances}

The results of the sensitivity analysis on the electricity mixes (Figure 6) indicate that the differences in environmental performances between the grid imports, OPV-only and OPV-battery systems are sensitive to the electricity grid mix compositions (Figure S1, ESI). Regardless of the country and the specific choice of electricity grid mixes, it is generally observed that the differences in environmental impacts between the three systems increase as the share of fossil fuels in the grid mixes increase. In grid mixes with high shares of fossil fuels (e.g. grid mixes in GR that rely mainly on lignite or average grid mix in DK that still includes coal; e.g. Fig. 6B,D-F), marked differences of impact scores are revealed for nearly all impact categories, with OPVbattery systems performing better than OPV-only systems, itself performing better than grid imports (with exceptions for negative impact indicator scores -see Section 4.2.1). In contrast, grid mixes with high renewables shares (e.g. wind power like for baseline scenario in DK; see Figure 6A), the differences of impact scores are less marked between the three systems, and for some impact categories, it is difficult to ascertain which alternative is preferable, particularly when considering potential uncertainties in the model (e.g. input data for industrial-scale OPV systems modelling) and impact assessment (see sensitivity on the impact assessment in Figure S3, ESI). These results therefore demonstrate that the environmental performances for OPV self-consumption are much dependent on the country considered, and that beyond the sole consequence of the geographical location on the technical performances of the OPV system (i.e. solar irradiation). From the two cases of Denmark and Greece, it may therefore be suggested that countries with high solar irradiation and fossils-based grid mix will show large environmental benefits in deployment of OPV self-consumption (preferably with batteries), whereas countries with relatively clean grid mixes and low solar irradiation may not advocate for OPV self-consumption. Although somewhat expected, these thus-proven trends may be used by energy policy-makers when developing energy strategies.

\section{Conclusions and recommendations}

Our economic analysis indicates that current battery costs need to drop by more than $10 \%$ for Greece and $30 \%$ for Denmark, so that battery storage becomes financially viable when associated with OPV system installations for residential self-consumption. From an OPV target costing perspective, we argue that battery storage can play a vital role in the future as OPV-battery systems will offer the most cost-effective solution compared to OPV-only systems, if OPV costs fall below $0.9 € / \mathrm{Wp}$ for Denmark and $1.6 € / \mathrm{Wp}$ for Greece, based on current battery costs. Furthermore, expected battery cost reductions will increase these cost thresholds thus reducing the gap before OPV-battery systems outperform OPV-only systems. OPV technology developers are thus encouraged to consider battery storage as an integral part of OPV systems for self-consumption applications. We also recommend that further research into the economic performance of OPV-battery systems be conducted due to their rapidly evolving costs and the emergence of new technologies.

With regard to environmental impacts, OPV technology developers should ensure that potential environmental trade-offs between impact categories are identified early in the technology development phase and addressed, e.g. through eco-design strategies. Results from our study can provide a good starting point. We thus recommend that OPV technology developers extend the scope beyond the sole OPV modules and integrate the balance of system, which was found to be a major contributor to the environmental burden of OPV systems as soon as OPV modules start having increased technical performances (efficiencies, lifetime, etc.). 
Chatzisideris M.D., Ohms P.K., Espinosa N., Krebs F.C., Laurent A., 2019. Economic and environmental performances of organic photovoltaics with battery storage for residential self-consumption. Applied Energy 256, 113977, 1-13. DOI: https://doi.org/10.1016/j.apenergy.2019.113977

Unlike previous studies, we built up on the economic analysis to gauge the environmental impacts of electricity self-consumption from OPV systems in Denmark and Greece. Results showed indications that OPVonly and OPV-battery systems tended to be associated with lower environmental impacts than electricity imports from the grid whenever the grid mix was associated with a high share of fossil fuels and a high solar irradiation, while inconclusive results were obtained with relatively clean electricity mixes and low solar irradiation. Together with the economic analysis, such studies as ours can help quantify the potential benefits of OPV systems in specific legislative, meteorological and demographic contexts and thus support energy policy-makers to target countries or regions, where deployment of OPV systems for self-consumption can bring the most benefits.

\section{Conflict of interest}

The authors declare no conflict of interest. 
Chatzisideris M.D., Ohms P.K., Espinosa N., Krebs F.C., Laurent A., 2019. Economic and environmental performances of organic photovoltaics with battery storage for residential self-consumption. Applied Energy 256, 113977, 1-13. DOI: https://doi.org/10.1016/j.apenergy.2019.113977

\section{References}

[1] IEA. World Energy Outlook 2018. International Energy Agency, Paris, FR, 2018.

[2] Breyer C, Bogdanov D, Gulagi A, Aghahosseini A, Barbosa LSNS, Koskinen O, Barasa M, Caldera U, Afanasyeva S, Child M, Farfan J, Vainikka P. On the role of solar photovoltaics in global energy transition scenarios. Prog. Photovolt: Res. Appl. 2017; 25:727-745. doi: 10.1002/pip.2885.

[3] Heinisch V, Odenberger M, Göransson L, Johnsson F. Prosumers in the electricity system-household vs. system optimization of the operation of residential photovoltaic battery systems. Front Energy Res 2019;6. doi:10.3389/fenrg.2018.00145.

[4] Parra D, Patel MK. The nature of combining energy storage applications for residential battery technology. Appl Energy 2019;239:1343-55. doi:10.1016/j.apenergy.2019.01.218.

[5] European Commission. Best Practices on Renewable Energy Self-consumption. Commission Staff Working Document, COM(2015) 339 final. EU Commission, Brussels, BE, 2015.

[6] Masson G, Briano JI, Baez MJ. Review and Analysis of PV Self-consumption Policies. Report IEAPVPS T1-28:2016. International Energy Agency (IEA) Photovoltaic Power Systems Programme, Paris, FR, 2016.

[7] EU Commission. Study on "Residential Prosumers in the European Energy Union". Authors: GfK Belgium Consortium. EU Commission, Directorate-General for Justice and Consumers (DG JUST), Brussels, BE, 2017. Available at: https://ec.europa.eu/commission/sites/beta-political/files/executivesummary-study-residential-prosumers_en.pdf (Accessed 22/05/2019).

[8] Roberts MB, Bruce A, MacGill I. Impact of shared battery energy storage systems on photovoltaic self-consumption and electricity bills in apartment buildings. Appl Energy 2019;245:78-95. doi:10.1016/j.apenergy.2019.04.001.

[9] Weniger J, Tjaden T, Quaschning V. Sizing of Residential PV Battery Systems. Energy Procedia 2014;46:78-87. doi:10.1016/j.egypro.2014.01.160.

[10] Krebs FC, Espinosa N, Hösel M, Søndergaard RR, Jørgensen M. 25th anniversary article: Rise to power - OPV-based solar parks. Adv Mater 2014;26:29-39. doi:10.1002/adma.201302031.

[11] Wang Q, Xie Y, Soltani-Kordshuli F, Eslamian M. Progress in emerging solution-processed thin film solar cells - Part I: Polymer solar cells. Renew Sustain Energy Rev 2016;56:347-61. doi:10.1016/j.rser.2015.11.063.

[12] Jørgensen M, Carlé JE, Søndergaard RR, Lauritzen M, Dagnæs-Hansen NA, Byskov SL, Andersen TR, Larsen-Olsen TT, Böttiger APL, Andreasen B, Fu L, Zuo L, Liu Y, Bundgaard E, Zhan X, Chen $\mathrm{H}, \mathrm{Krebs}$ FC. The state of organic solar cells - A meta analysis. Sol Energy Mater Sol Cells 2013;119:84-93. doi:10.1016/j.solmat.2013.05.034.

[13] Jean J, Brown PR, Jaffe RL, Buonassisi T, Bulović V. Pathways for solar photovoltaics. Energy Environ Sci 2015;8:1200-19. doi:10.1039/C4EE04073B.

[14] Krebs FC. Fabrication and processing of polymer solar cells: A review of printing and coating techniques. Sol Energy Mater Sol Cells 2009;93:394-412. doi:10.1016/J.SOLMAT.2008.10.004.

[15] Carlé JE, Helgesen M, Hagemann O, Hösel M, Heckler IM, Bundgaard E, Grevorgyan SA, Søndergaard RR, Jørgensen M, Garcia-Valverde R, Chaouki-Almagro S, Villarejo JA, Krebs FC. Overcoming the Scaling Lag for Polymer Solar Cells. Joule 2017;1:274-89. doi:10.1016/j.joule.2017.08.002.

[16] Machui F, Hösel M, Li N, Spyropoulos GD, Ameri T, Søndergaard RR, Jørgensen M, Scheel A, Gaiser D, Kreul K, Lenssen D, Legros M, Lemaitre N, Vilkman M, Välimäki M, Nordman S, Brabec 
Chatzisideris M.D., Ohms P.K., Espinosa N., Krebs F.C., Laurent A., 2019. Economic and environmental performances of organic photovoltaics with battery storage for residential self-consumption. Applied Energy 256, 113977, 1-13. DOI: https://doi.org/10.1016/j.apenergy.2019.113977

CJ, Krebs FC. Cost analysis of roll-to-roll fabricated ITO free single and tandem organic solar modules based on data from manufacture. Energy Environ Sci 2014;7:2792.

doi:10.1039/C4EE01222D.

[17] Fraunhofer Institute for Solar Energy Systems. Photovoltaics Report 2018. Fraunhofer ISE, Freiburg, DE, 2019.

[18] Hoppmann J, Volland J, Schmidt TS, Hoffmann VH. The economic viability of battery storage for residential solar photovoltaic systems - A review and a simulation model. Renew Sustain Energy Rev 2014;39:1101-18. doi:10.1016/j.rser.2014.07.068.

[19] Schram WL, Lampropoulos I, van Sark WGJHM. Photovoltaic systems coupled with batteries that are optimally sized for household self-consumption: Assessment of peak shaving potential. Appl Energy 2018;223:69-81. doi:10.1016/j.apenergy.2018.04.023.

[20] Gambhir A, Sandwell P, Nelson J. The future costs of OPV - A bottom-up model of material and manufacturing costs with uncertainty analysis. Sol Energy Mater Sol Cells 2016;156:49-58. doi:10.1016/j.solmat.2016.05.056.

[21] Mulligan CJ, Wilson M, Bryant G, Vaughan B, Zhou X, Belcher WJ, Dastoor PC. A projection of commercial-scale organic photovoltaic module costs. Sol Energy Mater Sol Cells 2014;120:9-17. doi:10.1016/j.solmat.2013.07.041.

[22] Chatzisideris MD, Laurent A, Christoforidis GC, Krebs FC. Cost-competitiveness of organic photovoltaics for electricity self-consumption at residential buildings: A comparative study of Denmark and Greece under real market conditions. Appl Energy 2017;208. doi:10.1016/j.apenergy.2017.10.003.

[23] Laurent A, Owsianiak M. Potentials and limitations of footprints for gauging environmental sustainability. Curr Opin Environ Sustain 2017;25. doi:10.1016/j.cosust.2017.04.003.

[24] Laurent A, Espinosa N, Hauschild MZ. LCA of Energy Systems (Chapter 26, pp. 633-668). In: Life Cycle Assessment: Theory and Practice (Eds. Hauschild M.Z., et al.). ISBN 978-3-319-56475-3. Springer, Dordrecht, NL, 2018.

[25] Chatzisideris MD, Espinosa N, Laurent A, Krebs FC. Ecodesign perspectives of thin-film photovoltaic technologies: A review of life cycle assessment studies. Sol Energy Mater Sol Cells 2016;156. doi:10.1016/j.solmat.2016.05.048.

[26] International Organization for Standardization. Environmental Management - Life Cycle Assessment Principles and framework (ISO 14040:2006). ISO, Geneva, CH, 2006.

[27] International Organization for Standardization. Environmental Management - Life Cycle Assessment Requirements and Guidelines (ISO 14044:2006). ISO, Geneva, CH, 2006.

[28] Espinosa N, Laurent A, Krebs FC. Ecodesign of organic photovoltaic modules from Danish and Chinese perspectives. Energy Environ Sci 2015;8. doi:10.1039/c5ee01763g.

[29] Hengevoss D, Baumgartner C, Nisato G, Hugi C. Life Cycle Assessment and eco-efficiency of prospective, flexible, tandem organic photovoltaic module. Sol Energy 2016;137:317-27. doi:10.1016/j.solener.2016.08.025.

[30] Tsang MP, Sonnemann GW, Bassani DM. Life-cycle assessment of cradle-to-grave opportunities and environmental impacts of organic photovoltaic solar panels compared to conventional technologies. Sol Energy Mater Sol Cells 2016;156:37-48. doi:10.1016/j.solmat.2016.04.024.

[31] Chatzisideris MD, Laurent A, Hauschild MZ, Krebs FC. Environmental impacts of electricity selfconsumption from organic photovoltaic battery systems at industrial facilities in Denmark. CIRP Ann - Manuf Technol 2017;66. doi:10.1016/j.cirp.2017.04.100. 
Chatzisideris M.D., Ohms P.K., Espinosa N., Krebs F.C., Laurent A., 2019. Economic and environmental performances of organic photovoltaics with battery storage for residential self-consumption. Applied Energy 256, 113977, 1-13. DOI: https://doi.org/10.1016/j.apenergy.2019.113977

[32] Longo S, Antonucci V, Cellura M, Ferraro M. Life cycle assessment of storage systems: the case study of a sodium/nickel chloride battery. J Clean Prod 2014;85:337-46. doi:10.1016/j.jclepro.2013.10.004.

[33] Laurent A, Espinosa N. Environmental impacts of electricity generation at global, regional and national scales in 1980-2011: what can we learn for future energy planning? Energy Environ Sci 2015;8:689-701. doi:10.1039/C4EE03832K.

[34] Palm J. Household installation of solar panels - Motives and barriers in a 10-year perspective. Energy Policy 2018;113:1-8. doi:10.1016/j.enpol.2017.10.047.

[35] Prete MI, Piper L, Rizzo C, Pino G, Capestro M, Mileti A, Pichierri M, Amatulli C, Peluso AM, Guido G. Determinants of Southern Italian households' intention to adopt energy efficiency measures in residential buildings. J Clean Prod 2017;153:83-91. doi:10.1016/j.jclepro.2017.03.157.

[36] Scarpa R, Willis K. Willingness-to-pay for renewable energy: Primary and discretionary choice of British households' for micro-generation technologies. Energy Econ 2010;32:129-36. doi:10.1016/j.eneco.2009.06.004.

[37] Klingler AL. Self-consumption with PV+Battery systems: A market diffusion model considering individual consumer behaviour and preferences. Appl Energy 2017;205:1560-70. doi:10.1016/j.apenergy.2017.08.159.

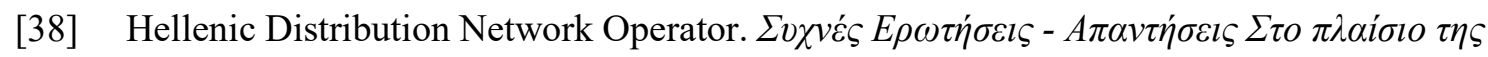

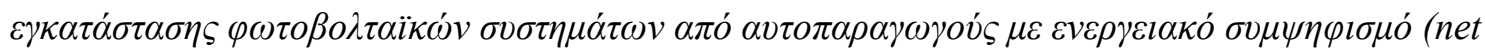
metering). HEDNO, Athens, GR, 2015.

[39] Weniger J, Tjaden T, Bergner J, Quaschning V. Sizing of Battery Converters for Residential PV Storage Systems. Energy Procedia 2016;99:3-10. doi:10.1016/J.EGYPRO.2016.10.092.

[40] Stenzel P, Baumann M, Fleer J, Zimmermann B, Weil M. Database development and evaluation for techno-economic assessments of electrochemical energy storage systems. In: IEEE International Energy Conference. IEEE; 2014. p. 1334-1342. doi:10.1109/ENERGYCON.2014.6850596.

[41] Baumann M, Peters JF, Weil M, Grunwald A. $\mathrm{CO}_{2}$ Footprint and Life-Cycle Costs of Electrochemical Energy Storage for Stationary Grid Applications. Energy Technol 2017;5:1071-83. doi:10.1002/ente.201600622.

[42] ecoinvent, Ecoinvent database v. 3. Available at: https://www.ecoinvent.org/database/database.html (Accessed 22/05/2019).

[43] Hesse H, Martins R, Musilek P, Naumann M, Truong C, Jossen A. Economic Optimization of Component Sizing for Residential Battery Storage Systems. Energies 2017;10:835. doi:10.3390/en10070835.

[44] Quoilin S, Kavvadias K, Mercier A, Pappone I, Zucker A. Quantifying self-consumption linked to solar home battery systems: Statistical analysis and economic assessment. Appl Energy 2016;182:5867. doi:10.1016/J.APENERGY.2016.08.077.

[45] Hauschild MZ, Goedkoop M, Guinée J, Heijungs R, Huijbregts M, Jolliet O, Margni M, De Schryver A, Humbert S, Laurent A, Sala S, Pant R. Identifying best existing practice for characterization modeling in life cycle impact assessment. Int J Life Cycle Assess 2013;18. doi:10.1007/s11367-0120489-5.

[46] PRé, SimaPro 8.5, https://simapro.com/ (Accessed 22/05/2019), PRé Consultants, Amersfoort, NL, 2014.

[47] Wernet G, Bauer C, Steubing B, Reinhard J, Moreno-Ruiz E, Weidema B. The ecoinvent database version 3 (part I): overview and methodology. Int J Life Cycle Assess 2016;21:1218-30. 
Chatzisideris M.D., Ohms P.K., Espinosa N., Krebs F.C., Laurent A., 2019. Economic and environmental performances of organic photovoltaics with battery storage for residential self-consumption. Applied Energy 256, 113977, 1-13. DOI: https://doi.org/10.1016/j.apenergy.2019.113977

doi:10.1007/s11367-016-1087-8.

[48] Treyer K, Bauer C. Life cycle inventories of electricity generation and power supply in version 3 of the ecoinvent database - part II: electricity markets. Int J Life Cycle Assess 2016;21:1255-68. doi:10.1007/s11367-013-0694-x.

[49] Schmidt JH, Merciai S, Thrane M, Dalgaard R. Inventory of country specific electricity in LCA Consequential and attributional scenarios. Methodology report v2. 2.-0 LCA consultants, Aalborg, DK, 2011. Available at: https://lca-net.com/publications/show/inventory-country-specific-electricitylca-consequential-attributional-scenarios-methodology-report-v2/ (Accessed 22/05/2019).

[50] Mathiesen BV, Münster M, Fruergaard T. Uncertainties related to the identification of the marginal energy technology in consequential life cycle assessments. J Clean Prod 2009;17:1331-8. doi:10.1016/j.jclepro.2009.04.009.

[51] Astudillo MF, Treyer K, Bauer C, Pineau P-O, Amor M Ben. Life cycle inventories of electricity supply through the lens of data quality: exploring challenges and opportunities. Int J Life Cycle Assess 2016. doi:10.1007/s11367-016-1163-0.

[52] Huijbregts MAJ, Steinmann ZJN, Elshout PMF, Stam G, Verones F, Vieira M, Zijp M, Hollander A, van Zelm R. ReCiPe2016: A harmonised life cycle impact assessment method at midpoint and endpoint level. Int J Life Cycle Assess 2017;22:138-147.

[53] Zhou Z, Carbajales-Dale M. Assessing the photovoltaic technology landscape: efficiency and energy return on investment (EROI). Energy Environ Sci 2018;11:603-8. doi:10.1039/c7ee01806a.

[54] Zhang Y, Samuel IDW, Wang T, Lidzey DG. Current Status of Outdoor Lifetime Testing of Organic Photovoltaics. Adv Sci 2018;5:1800434. doi:10.1002/advs.201800434.

[55] Kabakian V, McManus MC, Harajli H. Attributional life cycle assessment of mounted $1.8 \mathrm{kWp}$ monocrystalline photovoltaic system with batteries and comparison with fossil energy production system. Appl Energy 2015;154:428-37. doi:10.1016/j.apenergy.2015.04.125.

[56] McKenna E, McManus M, Cooper S, Thomson M. Economic and environmental impact of lead-acid batteries in grid-connected domestic PV systems. Appl Energy 2013;104:239-49. doi:10.1016/j.apenergy.2012.11.016.

[57] Peters JF, Baumann M, Zimmermann B, Braun J, Weil M. The environmental impact of Li-Ion batteries and the role of key parameters - A review. Renew Sustain Energy Rev 2017;67:491-506. doi:10.1016/j.rser.2016.08.039. 